\title{
ENGINEERING PROPERTIES OF SEA ICE
}

\author{
By J. Schwarz \\ (Hamburgische Schiffbau-Versuchsanstalt GmbH, Bramfelder Strasse 164, 2000 Hamburg 6o, \\ Germany)
}

and W. F. WEEKS

(U.S. Army Cold Regions Research and Engineering Laboratory, Hanover, New Hampshire 03755 , U.S.A.)

\begin{abstract}
As the continental shelves of the Arctic become important as source areas for the oil and minerals required by human society, sea ice becomes an increasing challenge to engineers. The present paper starts with a consideration of the different fields of engineering which require information on sea ice with the tasks ranging from the design of ice-breaking ships to Arctic drilling platforms and man-made ice islands. Then the structure of sea ice is described as it influences the observed variations in physical properties. Next the status of our knowledge of the physical properties important to engineering is reviewed. Properties discussed include mechanical properties (compressive, tensile, shear and flexural strengths; dynamic and static elastic moduli; Poisson's ratio), friction and adhesion, thermal properties (specific and latent heats, thermal conductivity and diffusivity, density) and finally electromagnetic properties (dielectric permittivity and loss, resistivity). Particular attention is given to parameters such as temperature, strain-rate, brine volume, and loading direction as they affect property variations. Gaps, contradictions in the data, and inadequacies in testing techniques are pointed out. Finally suggestions are made for future research, especially for more basic laboratory studies designed to provide the data base upon which further theoretical developments as well as field studies can be built.
\end{abstract}

Résumé. Propriétés de la glace de mer pour l'Ingénieur. Les plateaux continentaux de l'Arctique devenant importants comme réservoirs de pétrole et de minéraux nécessaires aux Sociétés humaines, la glace de mer devient un défi croissant aux Ingénieurs. Le présent article commence par considérer les différents domaines où l'Ingénieur a besoin d'informations sur la glace de mer avec des tâches allant du dessin de coques de navires brise-glace à des plates-formes pour forages arctiques ou à des îles de glace construites de main d'homme. Puis on décrit la structure de la glace de mer pour autant qu'elle influe sur les variations observées de ses propriétés physiques. On fait ensuite le point de nos connaissances sur les propriétés physiques importantes pour l'Ingénieur. Les propriétés discutées comprennent les propriété mécaniques (résistance à la compression, à̀ la tension, au cisaillement et à la flexion; modules élastiques, dynamiques et statiques; et coefficients de Poisson); friction et adhésion; propriétés thermiques (chaleurs latente et spécifique, conductivité et diffusivité thermiques, densité) et finalement propriétés électromagnétiques (constantes et pertes diélectriques, résistivité). On prête une particulière attention à des paramètres tels que la température, la vitesse de déformation, la teneur en sel et la direction de la charge en tant qu'ils affectent les variations de ces propriétés. Les lacunes et les contradictions dans les données expérimentales et les insuffisances dans les techniques d'essai sont mises en évidence. Finalement, on fait des suggestions pour de futures recherches, spécialement pour un développement des études de laboratoire destinées à fournir les données de base sur lesquelles pourraient être bâtis des développements théoriques supplémentaires aussi bien que des études sur le terrain.

Zusammenfassung. Ingenieurtechnische Eigenschaften des Meereises. Die Kontinentschelfe der Arktis gewinnen an Bedeutung als Lagerstätten von Erdöl und Mineralen, die von der menschlichen Gesellschaft benötigt werden; damit wird Meereis zunehmend zu einer Herausforderung für den Ingenieur. Die vorliegende Abhandlung beginnt mit einer Betrachtung der verschiedenen ingenieurtechnischen Arbeitsgebiete, die Kenntnisse über das Meereis voraussetzen, wobei die Aufgaben vom Entwurf von Eisbrechern bis zum Bau arktischer Bohrinseln und künstlicher Eisinseln reichen. Dann wird die Struktur des Meereises beschrieben, soweit sie für das Verständnis der beobachteten Schwankungen in den physikalischen Eigenschaften von Bedeutung ist. Anschliessend folgt eine Übersicht über unsere Kenntnis der physikalischen Eigenschaften mit ingenieurtechnischer Relevanz. Zu diesen gehören: mechanische Eigenschaften (Druck-, Zug-, Scherund Biegefestigkeit, dynamischer und statischer Elastizitätsmodul, Poisson-Verhältnis); Reibung und Adhäsion; thermische Eigenschaften (spezifische und latente Wärme, thermische Leitfähigkeit und Diffusion, Dichte); schliesslich elektromagnetische Eigenschaften (Dielektrizitätskonstanten, Dämpfung, Widerstand). Besondere Aufmerksamkeit wird Parametern wie der Temperatur, der Verformungsrate, dem Salzgehalt und der Belastungsrichtung gewidmet, soweit sie Schwankungen in den Eigenschaften bewirken. Lücken, widersprüchliche Daten und unzureichende Testverfahren werden hervorgehoben. Zuletzt folgen Vorschläge für zukünftige Untersuchungen, besonders für mehr Grundlagenforschung im Labor, mit dem Ziel, eine Ausgangsbasis zu gewinnen, auf der sowohl weitere theoretische Entwicklungen wie auch Felduntersuchungen aufbauen können. 


\section{INTRODUCTION}

Although descriptions of sea ice as an oceanographic oddity date from the time of Christ (Zukriegel, I935), the first serious study of it as an engineering material was undertaken in the I 890 os by Russian investigators in conjunction with cruises of the icebreaker Yermak (Makarov, I90 I ; Krylov, I90I). The purpose of these studies was to provide basic information needed to improve the capability of shipping to transit the ice-covered waters that commonly occur along so much of the Russian coast. During the I920's and ' 30 's, similar studies were made by other Russian scientists (Arnol'd-Alyab'yev, 1925, I939; Vaynberg and others, 1940) although the overall level of activity was low. By the start of the Second World War, some data were available on most of the engineering properties of sea ice although both the quantity and the quality of much of the information left something to be desired. Perhaps more important, a paper had been published (Tsurikov, 1940) suggesting that the variations in the strength of sea ice could be analyzed starting from models based on the internal structural arrangement of the liquid and gaseous inclusions in the ice. An excellent summary of the Russian work carried out prior to about r 940 can be found in Zubov (1945).

Following the Second World War, a variety of national groups showed interest in obtaining improved engineering information on sea ice. Soviet activity continued at an accelerated pace associated with increased shipping activity along the North Sea Route and the establishment of the Severnyy Polyus drifting stations in the Arctic Ocean. Finnish and Japanese investigators started to consider problems caused by the presence of pack ice in the Baltic and Okhotsk Seas while Canadians and Americans became involved in a variety of problems associated with sea and air resupply in the Arctic. This interest resulted in a number of programs that systematically attempted to enlarge our data base of engineering information particularly concerning the mechanical properties of sea ice.

At the same time, a theory was developed (Anderson and Weeks, 1958; Assur, 1958) that explained many of observed variations in the physical properties of sea ice in terms of more realistic models of the actual geometry of the brine and gaseous inclusions than were used by Tsurikov (1940, I947[a], [b]). As in earlier studies, many of the test procedures left much to be desired. Even so, the data and the theory were found to be in reasonable agreement. This is important in that the theory showed that most of the large observed variations in the mechanical properties of sea ice were produced by changes in the volume of void, both liquid and gaseous, in the ice. At least in first-year ice most voids are filled with brine, the volume of which is specified uniquely by the salinity and temperature of the ice. These two parameters are not difficult to measure, even under field conditions. Once they are determined, one can use them to obtain a brine volume and then by comparison with sets of tests on the parameter of interest, obtain a good estimate of its value in the field situation. In retrospect, research on the engineering properties of sea ice during this time period could be characterized as leisurely in that adequate time was usually available for reasonably thorough experiments and analysis. Also, the engineering problems that were being considered were modest: expanded navigation during the summer and longer air resupply capabilities during the winter via sea-ice runways. In addition, the stations that required such support were small, rarely involving more than a few hundred persons.

This ended in 1967 with the oil strike at Prudhoe Bay followed by the discovery of gas in the Mackenzie Bay area and in $1969-70$ by the cruises of the tanker Manhattan. The economic potential of the Arctic became generally recognized and development started at a rapid pace. Similar activities were also occurring in the coastal areas of the Soviet Arctic. The engineering problems that were now being posed were much more difficult; for example, year-round navigation on the margins of, and perhaps across, the Arctic Ocean; offshore drilling and oil and gas production from both coastal and deep-water sites on the Arctic Continental Shelf; the long-term use of both natural and artificially thickened sea ice to support very large loads, 
and the installation of pipelines between islands in the Canadian Archipelago. The solutions of these types of problems require a thorough knowledge of the engineering properties of sea ice coupled with information on the geophysical characteristics of the ice cover. For instance, once we know how to calculate the forces a multi-year pressure ridge can exert on an offshore structure, we must consider the probabilities of encountering ridges of different sizes with the final design being a judicious compromise between the value of development, the cost of construction, and the risk and environmental consequences of structural failure.

If the 1946-66 period of sea ice research was "leisurely", the period from 1967 to the present might best be described as "pandemonium". Once developmental activities started, it took only a short time to exhaust our basic-research bank account concerning sea ice. What disturbs us most is that, at the present, the pressures of providing the day-by-day sea-ice information required by operational problems have become so severe that little effort and even less funding is being devoted to improving our basic understanding of sea ice as a material.

In the present paper, we will first describe the structure of sea ice as it relates to models of the variation in its engineering properties. Then the current status of our knowledge of the more important engineering properties will be reviewed with emphasis on up-dating more detailed earlier discussions (Weeks and Assur, 1967, 1969), leading the reader to important references, and appraising the adequacy of the data. Finally, a number of suggestions will be made concerning research needs.

\section{EFFEGT OF SEA-ICE STRUCTURE}

Structurally undeformed first-year sea ice is very similar to a cast ingot. Its uppermost zone (the initial skim) is produced by the formation of the initial ice layer across the sea surface. This layer may vary from a few millimeters to $20 \mathrm{~cm}$ in thickness depending on the sea state at the time the ice cover forms. The layer below this can be referred to as the transition zone, in that a preferred growth orientation develops in the crystals. Although these upper two layers are quite interesting from a crystal-growth point of view, they are usually very thin (the base of the transition zone is commonly less than $30 \mathrm{~cm}$ below the upper surface of the ice sheet), and do not need to be considered for most engineering purposes.

During the melt season, the upper two layers commonly ablate away causing multi-year ice to be essentially completely composed of ice of the third zone. The ice of this so-called columnar zone characteristically has a strong preferred growth fabric with the crystals elongated vertically parallel to the direction of heat flow and the $c$-axes of the crystals oriented almost perfectly in the horizontal plane. This results in the basal planes of the ice crystals being oriented in a near-vertical direction. The geometric selection that occurs, as crystals with their $c$-axis oriented close to horizontal cut out other less fortunately oriented crystals, causes a gradual increase in grain size with depth at least in the upper portion of the ice sheet. In fact the very limited number of measurements of grain size (Weeks and Assur, 1967) suggests that the mean crystal diameter increases with depth at a rate independent of the grain size present at the base of the transition zone. Because the size of the crystals becomes large relative to that of the samples usually taken, adequate descriptions of grain-size variations are only available for the top $60 \mathrm{~cm}$ of first-year ice. Limited observations of the lower portions of $2 \mathrm{~m}$ thick ice show large areas (at least $\mathrm{I} \mathrm{m}$ in diameter) that have roughly collinear $c$-axis orientations (Peyton, 1966). Although the degree of colinearity is not sufficient for such areas to be considered as single crystals (unpublished results of A. J. Gow and W. F. Weeks), the degree of preferred orientation would clearly result in large variations in physical characteristics such as ice strength with changes in the direction of loading. In fact in the old sea ice, that was incorporated in the ice island ARLIS II, Smith (I964) reported areas of collinear $c$-axis that are as large as $10 \mathrm{~m}$ on a side, and recent studies of the anisotropy of the electrical 
characteristics of first-year ice have suggested that these domains may be very large (Campbell and Orange, I974).

Each individual crystal of sea ice is sub-divided into a number of ice platelets that are joined together to make a sort of a quasi-hexagonal network as viewed in the horizontal plane. It is within this network that most of the entrapped brine present in the sea ice is believed to be located. Figure I presents a schematic view of a cross-section of first-year sea ice. Also shown are several sketches made from thin sections showing both the individual crystals and the ice platelets, and a close-up of the brine pockets located between the platelets. The width of the platelets $a_{0}$, the so-called plate spacing, varies systematically with the ice growth velocity. Observations in metals suggest a fundamental relationship of the general form,

$$
a_{0} v^{\frac{1}{2}}=c,
$$

where $v$ is the growth velocity and $c$ is a constant. Limited observations on $a_{0}$ variations in $\mathrm{NaCl}$ ice (Lofgren and Weeks, I969) suggest that the power of $v$ may actually be a function of $v$. In any case, the slower the ice grows, the wider the ice platelets, resulting, in most situations, in $a_{0}$ increasing with increasing depth in the ice sheet. Other aspects of the geometry of these platelets or of the details of the geometry of the brine layers, channels and pockets have only received cursory examination. It is, however, reasonable to expect that they will also prove to be a function of the ice growth velocity.

One other aspect of the sea-ice substructure should be mentioned here. As the brine initially trapped between the ice platelets drains down and out of the ice sheet, it moves through structural features within the ice that have been referred to as brine drainage channels. These channels can be thought of as tubular river systems in which the tributaries are arranged with cylindrical symmetry around the main drainage channels. In first-year ice, such channels do not appear to reach above the base of the transition zone, presumably indicating that a

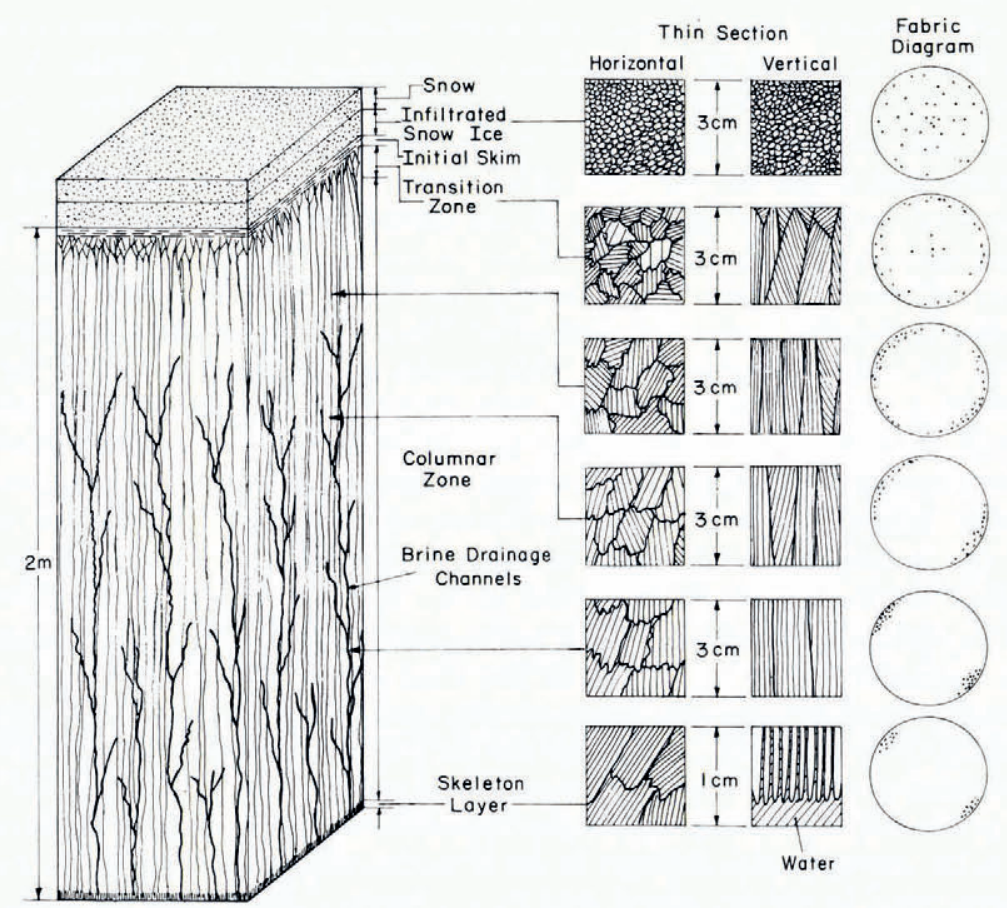

Fig. I. Schematic drawing showing several different aspects of the structure of first-year sea ice. 
certain volume of ice is required as a source of brine before a channel can form (or be identified). Near the bottom of thick annual sea ice, drainage channels appear to occur on a horizontal spacing of $\mathrm{I} 5$ to $20 \mathrm{~cm}$ and have a diameter of approximately $\mathrm{I} \mathrm{cm}$. The presence of drainage channels is also schematically illustrated in Figure $\mathrm{I}$.

Although all aspects of the structure of sea ice should influence its physical properties, at the present only the substructure associated with the presence of the ice platelets has been considered; all the salt is taken as entrapped in channels, layers, and pockets (or at very low temperatures as crystals of solid salt) between these plates. A drawing showing this idealization as developed by Assur (1958) is given as Figure 2. It is also assumed that the failure planes within each ice crystal will largely coincide with the planes along which the salt is concentrated. This assumption is borne out by a limited number of observations of the

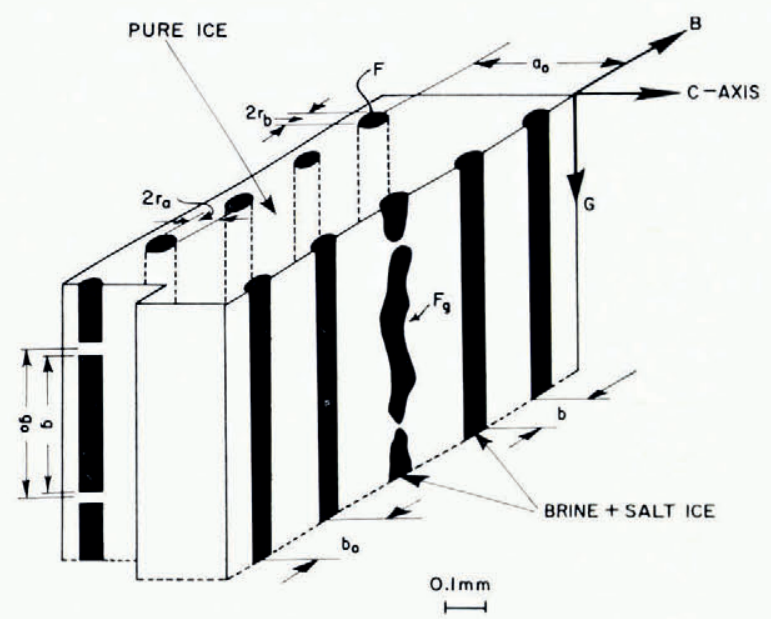

Fig. 2. Idealized diagram showing the shape of the brine inclusions in sea ice and parameters used to describe them (Assur, 1958).

geometry of actual failure surfaces in natural sea ice (Anderson and Weeks, 1958; Tabata, 1960). The reason for this coincidence is that the salt inclusions reduce the effective crosssectional area of ice-to-ice bonding between the plates causing the interplate boundaries to be planes of weakness. Therefore it is reasonable to suppose that variations in the failure strength $\sigma_{f}$ of sea ice can be expressed in the general form

$$
\frac{\sigma_{\mathrm{f}}}{\sigma_{0}}=\mathrm{I}-\psi \text {, }
$$

where $\psi$ is the plane porosity (the relative reduction in the area of the failure surface caused by the presence of gaseous and liquid inclusions) and $\sigma_{0}$ is the so-called basic strength of sea ice (the strength of an imaginary material containing no brine or air but still possessing the sea-ice substructure). The critical value of $\psi$ along the failure plane is

$$
\psi=\mathrm{f}(\nu)=\mathrm{f}\left(\nu_{\mathrm{a}}+\nu_{\mathrm{b}}\right) \text {. }
$$

where $\nu, \nu_{\mathrm{a}}$, and $\nu_{\mathrm{b}}$ are respectively the volume of void, or the porosity, of air and of brine. It then only remains to express $\psi$ in terms of $\nu$ via a model for the geometry of the inclusions. This has been done by Assur (1958), Anderson and Weeks (1958), and Anderson (1958[a], r 960 ). Details on these treatments can be found in Weeks and Assur (1967, 1969) and need not concern us here. The results of the analysis give an equation of the general form 


$$
\frac{\sigma_{\mathrm{f}}}{\sigma_{0}}=\mathrm{I}-c \nu^{k},
$$

where $c$ and $k$ are constants the values of which depend upon how the geometry of the fluid inclusions varies with changes in $\nu$. Models that have been considered include ones in which the brine pockets remain a constant width $(k=\mathrm{I})$ or show geometric similarity on a horizontal plane $\left(k=\frac{1}{2}\right)$ or in space $\left(k=\frac{2}{3}\right)$. In fact the detailed petrographic observations necessary to indicate which model most closely approximates reality are lacking. However, most recent authors have satisfactorily used $k=\frac{1}{2}$ to correlate changes in $\sigma_{\mathrm{f}}$ with changes in $\nu$ and we will also present available data in this form. On such plots the value of $\sigma_{0}$ is given by the intercept of the linear extension of the least-squares straight line through the data with the $\sigma_{\mathrm{f}}$ axis.

As will be discussed later, similar variations in many other physical properties of sea ice are also caused by changes in $\nu$. It is upon this dependence that the estimation of the engineering properties of sea ice is usually based. Design values are usually extreme values which are difficult to measure in the field because they occur so rarely. However, if the value of $v$ associated with the extremes can be estimated, then one can simply determine the value of the physical property of interest from its measured or extrapolated dependence upon $\nu$. In fact, this is not too difficult to do because the salinity of sea ice changes rather systematically with ice thickness and age. Attempts to present these types of correlations for both average salinities and salinity profiles can be found in Weeks and Assur (1967, 1969), Cox and Weeks (1974), and Tsurikov (1976). This compositional information can then be combined with representative ice temperatures, which can be estimated from information in Peschanskiy (1967), Maykut and Untersteiner (1969), and Maykut (I976).

For instance, if we are interested in the tensile strength and elastic modulus profiles for $0.2,0.8$ and $3.0 \mathrm{~m}$ thick ice in the Arctic Basin on roughly I May, we would expect values
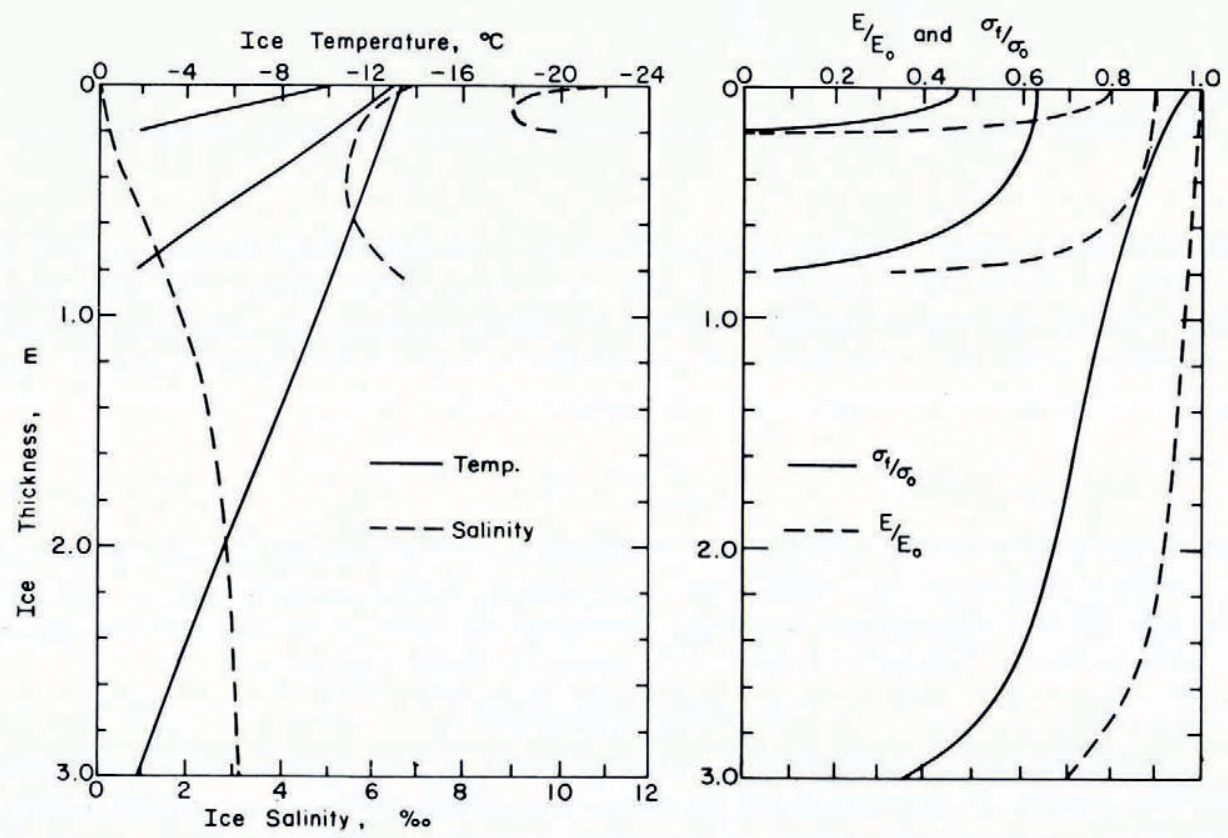

Fig. 3. Representative sea-ice temperature, salinity, $E / E_{0}$ and $\sigma_{\mathrm{f}} / \sigma_{0}$ profiles for $0.2,0.8$, and $3.0 \mathrm{~m}$ thick Arctic sea ice on $\mathrm{c}$. $I$ May. To convert $\sigma_{\mathrm{f}} / \sigma_{0}$ to $\sigma_{\mathrm{f}}$ and $E / E_{0}$ to $E$ multiply by $10.3 \times 10^{5} \mathrm{~N} / \mathrm{m}^{2}$ and by $10^{10} \mathrm{~N} / \mathrm{m}^{2}$ respectively based on the flexural strength determinations by Dykins (I97I) and the elastic modulus measurements by Langleben and Pounder (I963). 
similar to the profiles shown in Figure 3. Here we have converted the estimated salinity and ice temperature profiles to a brine volume profile via the empirical relation developed by Frankenstein and Garner ( 1967 ) from the brine volume tables for standard sea ice worked out by Assur (1958). In doing this, we have not taken account of the volume of gas entrapped within the ice. Although for first-year ice this volume is usually believed to be small relative to the brine volume, this may not be true for multi-year ice. In converting from brine volume profiles to $\sigma_{\mathrm{f}} / \sigma_{0}$ and $E / E_{0}$ profiles, the equations suggested by Dykins (I97 I) and by Langleben and Pounder $(1963)$ for flexural strength and dynamically determined elastic modulus were used. As will be discussed later, the problems in preparing such profiles are primarily caused by uncertainties in the values of the engineering parameters of interest near the melting point (large $\nu$ ) and at temperatures colder than $-23^{\circ} \mathrm{C}$ (presence of significant amounts of solid salt in the ice). Once adequate physical property profiles have been obtained either by the methods that we have described or by direct measurement, methods for deducing proper composite characteristics for the ice can be applied (Assur, 1967; Weeks and Assur, r967).

\section{ENGINEERING PROPERTIES OF SEA ICE}

There are, of course, a large number of material characteristics of sea ice that can legitimately be considered of engineering interest. Fortunately, in most problems one needs to be concerned with only a small number of these. We can discern what these properties are by listing first some of the more important applied areas of concern, then a few more specific problems in each of these areas, and finally the engineering properties of sea ice required to resolve these problems. This is done in Table I. Although this table does not attempt to provide an inclusive list of problems, it is clear that certain engineering properties of sea ice would occur over and over in any such list that is prepared. These are the mechanical properties as they relate to both short-term and long-term loading and to ultimate failure of

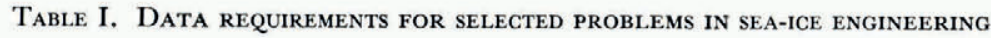

\section{General problem areas}

I. Ships transiting sea ice

2. Design of off-shore structures for Arctic sites

3. Large loads on ice
sheets

4. Ice scoring of the sea floor

\section{Specific problems}

(a) Ice resistance during breaking

(b) Impact loads on hull plates

(c) Forces exerted by converging ice

(d) Ice reconnaissance

(e) Ice forecasting

(a) Ice forces on structures

(b) Estimation of ice pile-ups

(c) Abrasion of structural elements

(d) Ice erosion of gravel islands

(e) Remote sensing of ice thickness

(f) Hindcasting of ice dynamics

(a) Calculation of short term failure

(b) Calculation of long-term creep

(c) Remote sensing of ice thickness

(a) Forces exerted by grounded ice features

(b) Ice reconnaissance

(c) Hindcasting of coastal ice motion

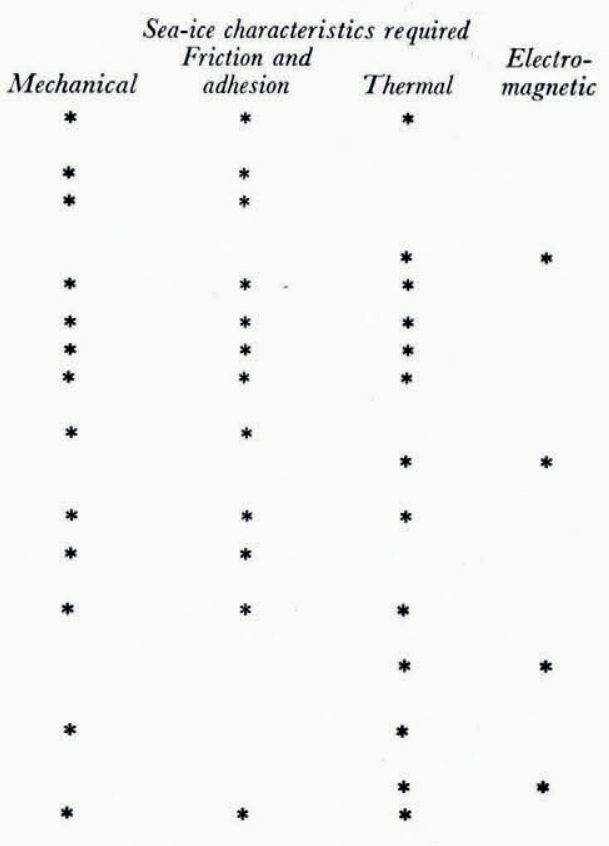


the ice, the frictional properties which must be considered when ice bonds to or moves relative to either an engineering structure or to itself, and the thermal properties which are essential to any problem in which ice growth or the change in temperature of the ice is important. Finally, there are the electromagnetic properties of the ice which must be understood to obtain maximum benefit from the application of current remote-sensing technology to sea ice. It is these techniques that will provide the requisite descriptions of areas of pack ice that should be available before sound engineering calculations can start.

\section{Mechanical PROPERTIES}

Although sea ice is the main engineering concern in the development of Arctic navigation and off-shore technology its mechanical properties have been investigated far less than those of fresh-water ice. In fact, in the last four symposia dealing with the engineering aspects of ice in which $25^{\circ}$ papers were presented, only ro dealt with the mechanical properties of sea ice. One reason for this situation is that properties such as failure strength, elasticity, plasticity, stress-strain behavior, and the fracture modes under various load conditions are presumably complicated by the presence of brine inclusions, which do not occur in relatively pure freshwater ice. Also frozen lakes are readily accessible from many locations while studies of sea ice invariably involve considerable logistic effort and expense.

Even though some work has been done on each of the mechanical properties, the evaluation and comparison of results is, at best, difficult, since the methods of testing commonly differ from one investigator to another. This lack of standardization has proven to be such a problem that the Committee on Ice Problems of the International Association for Hydraulic Research (IAHR) has formed a Standardization Task Group to make recommendations in this regard. We will refer to their first report (IAHR, I975) several times in the following discussion.

\section{STRENGTH}

\section{General conditions}

Proper procedures for testing sea-ice strength require the recording of the following subsidiary information:

(a) ice type (specified according to some general classification),

(b) ice temperature, salinity, and gas content,

(c) size and orientation of ice crystals,

(d) sample dimensions and load direction,

(e) history of the ice sample including its location in the ice sheet,

(f) strain-rate,

(g) end condition of the sample (nature of the interface between the ice and the loading platens),

(h) failure mode.

Collecting all these data is both time-consuming and laborious. This may be another reason why the number of investigations on sea-ice strength is extremely small. Only rarely do available results satisfy all these requirements for basic information.

In reviewing the various mechanical properties of sea ice we will try to both identify the gaps in existing knowledge and suggest ways in which the present situation can be improved.

\section{Compressive strength}

(a) Testing procedures

In the conventional uniaxial compression test, axial force is applied to the ends of a specimen through steel platens that make direct contact with the test specimen. Friction 
between platen and specimen produces radial restraint, so that there is commonly a triaxial state of stress near the end planes. The triaxial field is significant over an axial distance from the end planes of about one specimen radius. Interposition of highly compliant sheets (elastic or plastic) between the platens and the specimen often changes the sign of radial end forces, but does not eliminate the triaxial stress state. On a different scale, irregularities in the specimen end planes also create localized stress perturbations, and in brittle material these commonly initiate microcracks that lead to premature failure of the specimen.

Most attempts to overcome all these difficulties have been unsuccessful. Therefore the usual procedure has been to use a specimen that is long enough to provide a mid-section that is reasonably free from end-effect stress perturbations.

The International Association for Hydraulic Research (IAHR) Standardization Task Group has suggested a new method for testing ice in compression by using low-modulus urethane which is laterally confined by an aluminum cylinder to prevent radial deformation. This method has been tested and found to be satisfactory in the sense of providing reasonable approximation to a uniaxial state of stress throughout the specimen. It also allows for reasonable tolerances in specimen preparation and permits the use of smaller specimens. For more information see either the Task Group report (IAHR, I975) or Haynes and Mellor (1977). However, as of the present, this method has not been utilized in studies of sea ice.

(b) Load direction

The earliest simple compression tests on cylinders of sea ice were carried out by Butkovich (1956, 1959) who obtained strength values ranging from $76 \times \mathrm{Io}^{5} \mathrm{~N} / \mathrm{m}^{2}$ at $-5^{\circ} \mathrm{C}$ to roughly $120 \times 10^{5} \mathrm{~N} / \mathrm{m}^{2}$ at $-16^{\circ} \mathrm{C}$ from vertical cores. Average values on horizontal cores in the same temperature range varied from $2 \mathrm{I} \times 10^{5}$ to $42 \times 10^{5} \mathrm{~N} / \mathrm{m}^{2}$. A similar strong orientation dependence was found by Peyton (ig66) who ran tests on a large number of samples of different sea-ice petrographic types at various orientation and stress rates (Fig. 4). The ice Peyton used characteristically had grain sizes larger than the diameter of his specimen. Therefore, his samples were essentially single crystals with their $c$-axes oriented parallel to the plane of the ice sheet. In Figure 4 the loading-angle notation is as follows: the first number gives the angle between the axis of the test cylinder and the vertical, while the second number gives the angle between the sample and the $c$-axis of the single ice crystal being tested. Note that the ratio of the strength obtained from vertical cores to that obtained from horizontal cores is about 3 to I which is in agreement with the results of Butkovich (1959).

In contrast to these findings are results of compressive strength tests carried out by Schwarz ([197I]) on saline ice from the western part of the Baltic Sea. The salinity of this ice was

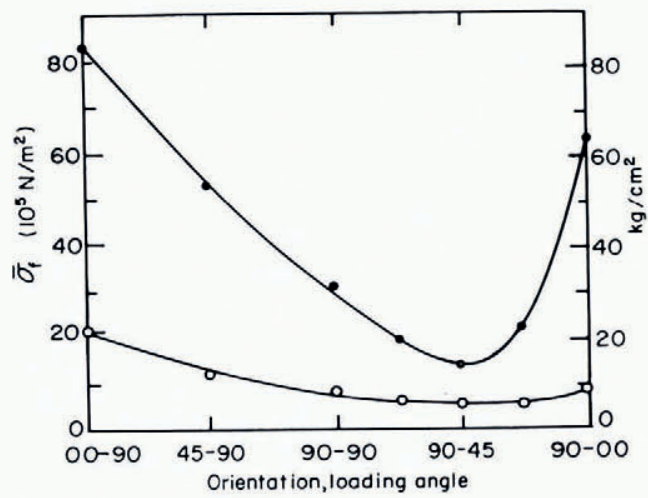

Fig. 4. Average failure strength in compression (solid circles) and in direct tension (open circles) versus sample orientation: bottom ice, $-10^{\circ} \mathrm{C}$ (Peyton, 1966$)$. For orientation notation see text. 


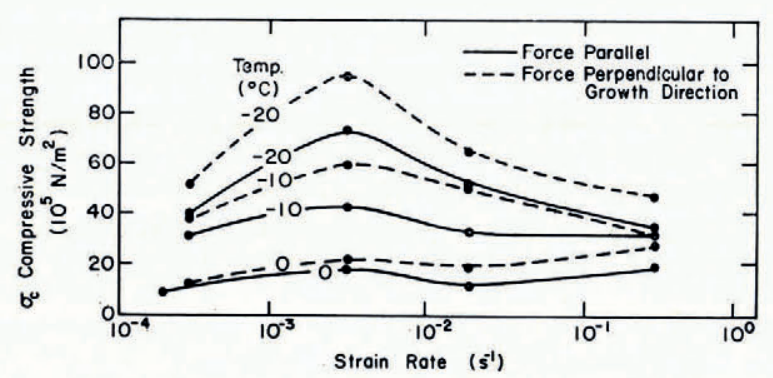

Fig. 5. Compressive strength of Baltic Sea ice as a funclion of strain-rate, ice temperature, and orientation of the force (Schwarz, [1971]).

$2.7 \%$ due to the high rate of freezing ( $12 \mathrm{~cm}$ in $36 \mathrm{~h}$ ). As shown in Figure 5 , the strength was about $20 \%$ higher when the ice was compressed in the horizontal rather than in the vertical direction. Because similar results in respect to the effect of the direction of load on the compressive strength have reportedly been obtained in proprietary studies sponsored by oil companies, the whole matter needs to be reconsidered. In further studies the failure mode and the strain conditions in the three principal directions of deformation as well as the structure of the ice should be investigated in order to remove some of the ambiguity in explaining the results.

It has been argued in explaining Peyton's and Butkovich's results that the grain boundaries and the basal planes of individual crystals, which are the planes where the brine pockets are located, are oriented so the specimen will fail easier when loaded perpendicular to the direction of growth. Other arguments can be formulated to explain Schwarz's results: sea ice fails most easily in tension by separation of the ice crystals along their long axis. This is what has been observed to happen in the uniaxial state of stress when a sample is loaded parallel to the direction of growth (which is also the direction of the long axes of the crystals) and subsequently fails by tensile strain perpendicular to the direction of load ( Wu and others, г976).

(c) Brine volume

Peyton's results on the variation of the compressive strength of sea ice with changes in the brine volume are shown in Figure 6 . Here $\sigma_{\mathrm{R}}$ is a strength index (the measured compressive strength corrected for variations in the rate of application of the stress; $\sigma_{\mathrm{R}} \equiv \sigma_{\mathrm{c}} / \dot{\sigma}^{b}$ where $\sigma_{\mathrm{c}}$

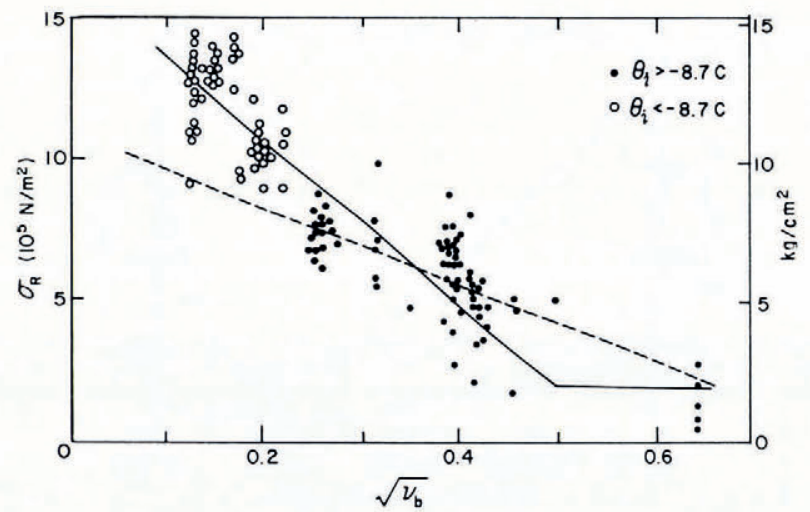

Fig. 6. $\sigma_{\mathrm{R}}$ from compression tests versus square root of the brine volume (Peyton, 1966). For the difference between the solid and dashed lines see discussion in text. 
is the compressive strength, $\dot{\sigma}$ is the rate of stress application and $b$ is an experimental constant equal to o.22). Different interpretations can be placed on this data as indicated by the solid and dashed lines. The solid line suggested by Weeks and Assur (1967) is

$$
\sigma_{\mathrm{R}}=\mathrm{I} 6.5 \times 1 \mathrm{I}^{5}\left\{\mathrm{I}-\left(\nu_{\mathrm{b}} / 0.275\right)^{\frac{1}{2}}\right\} \mathrm{N} / \mathrm{m}^{2},
$$

where $\sigma_{\mathrm{R}}$ was defined as mentioned and $\nu_{\mathrm{b}}$ is the absolute value of the brine volume. This relation holds only at $\nu_{\mathrm{b}} \leqslant 0.25$. At higher values of $\nu_{\mathrm{b}}, \sigma_{\mathrm{R}}$ is assumed to be constant independent of $\nu_{\mathrm{b}}$ in agreement with similar observations in in-situ cantilever beam tests, shear tests and ring-tensile tests. The dashed line, suggested by Peyton (1966), will be discussed later. The significant feature in these results is that both sets of investigators felt that $\sigma_{R}$ could be adequately expressed as a function of the square root of the brine volume.

(d) Temperature

The effect of temperature on the compressive strength has only been considered in connection with the brine volume. Peyton found the ice strength obtained at temperatures below $-8.7^{\circ} \mathrm{C}$ to be significantly greater than extrapolated values based only on tests from warmer ice (see the dashed line in Figure 6). This was explained by the fact that at $-8.7^{\circ} \mathrm{C}$ $\mathrm{Na}_{2} \mathrm{SO}_{4} \cdot \mathrm{IOH}_{2} \mathrm{O}$ starts to precipitate. This solid salt was suggested to strengthen the ice in a manner similar to steel in concrete. Tests of Schwarz ([197I]) lend some support to this explanation since his investigation on saline ice from the Baltic Sea shows a relatively steeper increase of the strength between -10 and $-20^{\circ} \mathrm{C}$ compared with equivalent tests on freshwater ice (Fig. 7). The results are hardly conclusive.

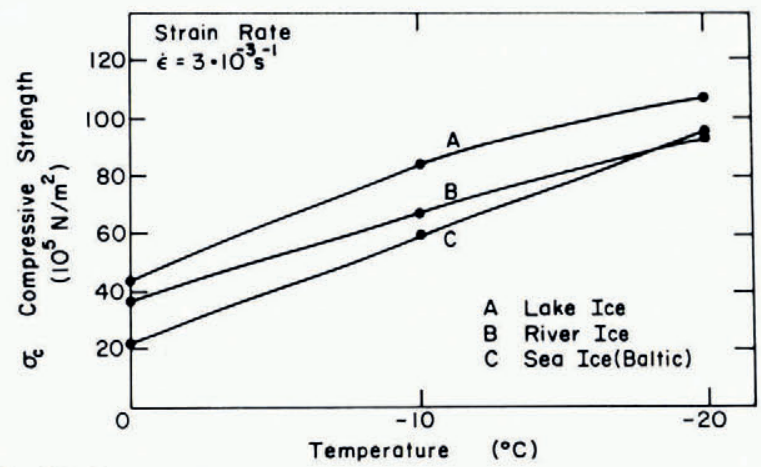

Fig. 7. Compressive strength of Baltic ice and freshwater ice as a function of temperature (Schwarz, [r97I]). Load applied perpendicular to the growth direction.

(e) Strain-rate

From compressive strength tests on fresh-water ice we know that ice has a failure strength maximum at a certain strain-rate. In this respect Peyton found contradictory results for sea ice from different locations. For sea ice from Point Barrow the strength increased with the stress rate while for sea ice from Cook Inlet the strength decreased when tested at the same loading rates.

In spite of these non-conclusive results Peyton expected the failure strength to have a maximum at a certain stress rate. This assumption was confirmed by Schwarz ([197I]) who investigated the strength of saline ice from the Baltic Sea at different strain-rates and temperatures. The results given in Figure 5 clearly indicate a maximum failure strength at a strain rate of about $1 \mathrm{O}^{-3} \mathrm{~s}^{-1}$ which is associated with the transition between creep-ductile and brittle failure. The same phenomenon has been found in compression tests of fresh-water ice (Carter, [1972]; Korzhavin, r962; Wu and others, r976; Schwarz [197r]). There is still discussion 
as to whether or not the compressive strength decreases at higher strain-rates. Carter ([1972]) explains the decrease of strength at higher strain-rates by energy considerations. He shows that the stress concentrations occurring at the tip of cracks are reduced by plastic deformation. Therefore at high strain-rates there is less time for plastic deformation and as a result the strength decreases. Hawkes and Mellor (1972) believe the decrease is a result of poor experimental methods. With the new testing method suggested by the I.A.H.R. Standardization Task Group and also with the improvements in available testing machines it should be possible to establish reliable results on such relationships. Furthermore, ice temperature should not be overlooked as an important parameter in connection with the strain-rate. This has, as yet, not been investigated for sea ice, but from testing fresh-water ice (Carter, [1972]; Wu and others, 1976) we know that the relation between strength and strain-rate is temperature dependent. Due to the correlation between temperature and the brine volume of the ice, the strain-rate effect will also be a function of the brine volume.

\section{(f) Size effect}

Investigations on fresh-water ice have shown that the compressive strength increases if the ratio of crystal size to sample size exceeds a certain value. This so called "size effect" has not, as yet, been investigated for sea ice. Due to the substructure of the crystals and the possibility of easy crack propagation across the crystals on planes of impurities it is very likely that the size effect will not occur in sea ice. This, of course, needs to be proven.

\section{(g) Conclusions}

The controversial results and the gaps of knowledge on the uniaxial compressive strength of sea ice should be a challenge for further intensive studies on this subject. In order to be able to make both qualitative and quantitative comparisons of the results of different investigators it is suggested that the recommendations for testing ice in compression of the I.A.H.R. Standardization Task Group be carefully considered in designing any such studies.

\section{Tensile strength}

Uniaxial tensile strength can only be determined unambiguously through direct tension tests. Any substitute for direct testing methods such as ring-tensile, brazil, or beam tests induces complicated stress states within the sample which require assumptions about the stress-strain relationship before strength values can be calculated from the test results.

The most comprehensive work on the tensile strength of sea ice has been carried out by Dykins (1970) and has also been summarized by Katona and Vaudrey (1973). The ice investigated was frozen from sea-water in a laboratory tank to simulating freezing conditions in nature. The salinity within the ice was I to $2 \%$ (brackish ice) and 8 to $9 \%$ (sea ice). By varying the temperature, a wide range of brine volumes was investigated. The tests were carried out on dumb-bell specimens which were attached to the testing machine by gripping heads. A similar method in which the ice was frozen to metal end cups has been used by Hawkes and Mellor (1972). Both methods provide a fairly accurate uniaxial state of stress as photoelastic observations by G. D. Vaudrey (personal communication) have shown. With minor improvements by Hawkes and Mellor (1972) this method has been suggested for tension tests by the Standardization Task Group.

Dykins' (1970) results have shown a very strong difference in the tensile strength depending on the direction of load: the ice was two to three times stronger when the tension was applied in the vertical direction than in the horizontal (Fig. 8). This result supports the compression test results on sea ice of Schwarz (Fig. 5), since compression applied in the vertical direction induces tensile strain in the lateral direction.

Figure 8 shows that the tensile strength, in the vertical as well as horizontal loading direction, can be adequately expressed as a function of the square root of the volume, similar 


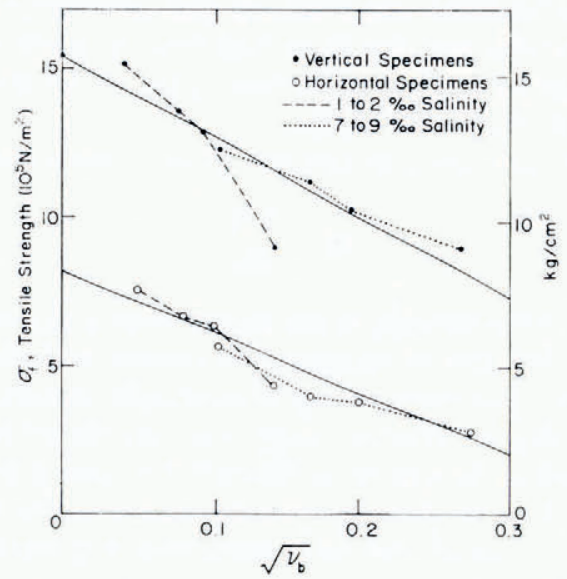

Fig. 8. Tensile strength of sea ice versus the square root of the brine volume (Dykins, 1970).

to the case for compressive strength. The equations derived from the two curves of Figure 8 are:

$$
\begin{aligned}
\sigma_{\mathrm{t}}(\text { vertical }) & =\mathrm{I} 5.4 \times 10^{5}\left\{\mathrm{I}-\left(\nu_{\mathrm{b}} / \mathrm{O} .3 \mathrm{II}\right)^{\frac{1}{2}}\right\} \mathrm{N} / \mathrm{m}^{2}, \\
\sigma_{\mathrm{t}}(\text { horizontal }) & =8.2 \times 10^{5}\left\{\mathrm{I}-\left(\nu_{\mathrm{b}} / 0.14^{2}\right)^{\frac{1}{2}}\right\} \mathrm{N} / \mathrm{m}^{2} .
\end{aligned}
$$

Dykins stated that the tensile strength was not appreciably dependent on the crystal size. Since the ratio of dumb-bell diameter to crystal diameter was as low as five, the so-called size effect should have shown up if it is present in sea ice. These results indicate that the substructure of a sea-ice crystal works like the grain boundaries in fresh-water ice in respect to easy crack propagation.

Limited studies on the effect of stress rates on the tensile strength show strength to be insensitive to stress rates ranging from $\dot{\sigma}=\mathrm{I} \times \mathrm{IO}^{3}$ to $\dot{\sigma}=\mathrm{I} .8 \times 10^{5} \mathrm{~N} / \mathrm{m}^{2} \mathrm{~s}$. A similar result was found by Hawkes and Mellor (1972) in tensile tests on fine-grained fresh-water ice. However, for stress rates greater than $1.8 \times 10^{5} \mathrm{~N} / \mathrm{m}^{2} \mathrm{~s}$, Dykins (1970) observed that the tensile strength decreased by $52 \%$ of the initial value. This result can be explained by the higher number of stress concentrators within sea ice in the form of brine pockets and air bubbles which become more effective at higher stress- or strain-rates.

Even though the tensile-strength tests of Dykins were carried out well, more testing of the tensile strength is necessary to confirm his results and to answer remaining questions such as the strain effect in relation to the brine volume, the precipitation of solid salts and their influence on the tensile strength, and the failure mode at various strain-rates. Further testing should also be expanded to include tensile-strength behavior under three-dimensional stress states.

\section{Flexural strength}

The flexural strength is not a basic material property but only an index strength. It is normally obtained by two different test methods: simply-supported beam tests or cantilever beam tests. The cantilever beam tests have an advantage in that they can be easily carried out in the field, thereby avoiding major brine drainage.

As Gow (1977) has shown in a paper presented earlier at this conference, cantilever beam tests on fresh-water ice provide a flexural strength which is up to $50 \%$ less than the flexural strength obtained from simply supported beams. Gow suggests that this difference is the result of stress concentrations occurring at the butt end of the beams. In sea ice such significant 
differences in strength have not been reported; on the contrary, it has been stated (Frankenstein, I968) that the results obtained by these two testing methods vary only slightly. This characteristic of sea ice is probably due to its more plastic behavior which relieves the stress concentrations and results in higher strengths.

The flexural strength of cantilever beams has usually been calculated as

$$
\sigma_{\mathrm{P}}=\frac{6 P l}{b h^{2}},
$$

where $P$ is the failure load, $l$ the length, $b$ the width, and $h$ the thickness of the beam.

This equation assumes that the deformation is elastic and the material is both isotropic and homogeneous. Sea ice, however, is an anisotropic material with a non-linear stress distribution over the beam depth. Hutter (1973) has developed an equation which considers these conditions; its application, however, is difficult, because it requires the establishment of a stress distribution according to the temperature and salinity gradient. Therefore, for practical uses and for the purpose of obtaining some index strength the equation given above may be sufficient.

On the other hand we should not forget that certain controversial results have been reported, for example by Lavrov (1969), using the equation based on the elastic theory for beams of different dimensions. It is very likely that these and other peculiar results of ice tests are due to the incorrect assumptions with regards to the material properties. If, for practical reasons we continue to use equations based on the elastic theory for calculating the flexural strength, then more testing is necessary to elucidate the size effect and to standardize the testing methods, i.e. beam preparation, loading conditions, etc.

Many investigators have determined values for the flexural strength of sea ice. The relation between brine content and flexural strength as determined from in-situ cantilever beam tests is particularly consistent, as shown in the investigations of Weeks and Anderson (1958), Brown (1963), and Butkovich (1956) (Fig. 9). From Figure 9, the equation obtained for $\sigma_{\mathrm{f}}$ as a function of $\nu_{\mathrm{b}}$ is

$$
\sigma_{\mathrm{f}}=7.5 \times 10^{5}\left\{\mathrm{I}-\left(\nu_{\mathrm{b}} / 0.202\right)^{\frac{1}{2}}\right\} \mathrm{N} / \mathrm{m}^{2},
$$

for $\nu_{\mathrm{b}}{ }^{\frac{1}{2}}<0.33$. These results suggest that the flexural strength remains roughly constant for brine volumes for which $\nu_{\mathrm{b}}{ }^{\frac{1}{2}}>0.33$. However, this constancy of strength was not obtained by Schwarz (1975) in his investigation of high salinity ice produced for model studies.

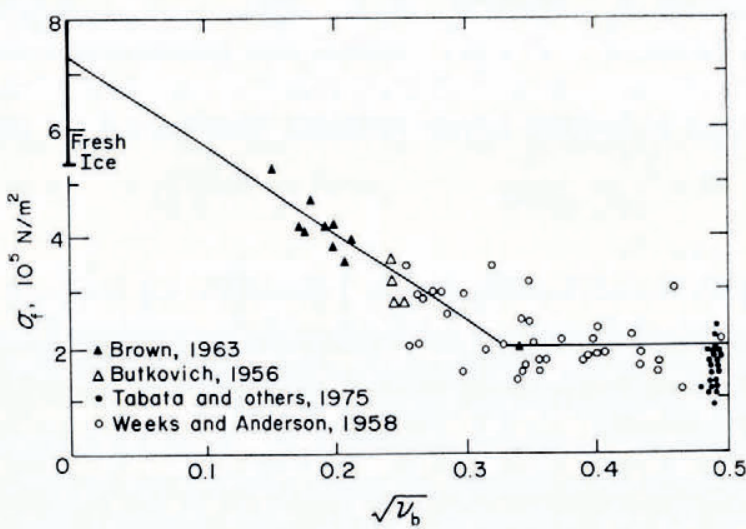

Fig. 9. Flexural strength measured by in-situ cantilever beam tests versus square root of the brine volume. 
The most recent and extensive work on the flexural strength was done by Dykins (197I) who tested large $i n$-situ beams with ice thicknesses of up to $2.4 \mathrm{~m}$. His test results (see Fig. Io) are well described by the equation

$$
\sigma_{\mathrm{f}}=\mathrm{I} 0.3 \times 10^{5}\left\{\mathrm{I}-\left(\nu_{\mathrm{b}} / 0.209\right)^{\frac{1}{2}}\right\} \mathrm{N} / \mathrm{m}^{2} .
$$

A comparison of the results of Figures 9 and ro shows that in both cases the curves have similar slopes as well as similar intercepts on the flexural-strength axis. This strongly suggests that external stress concentrations at the sharp corner of the butt of the cantilever are quite small. This had been already postulated by Frankenstein (1968).

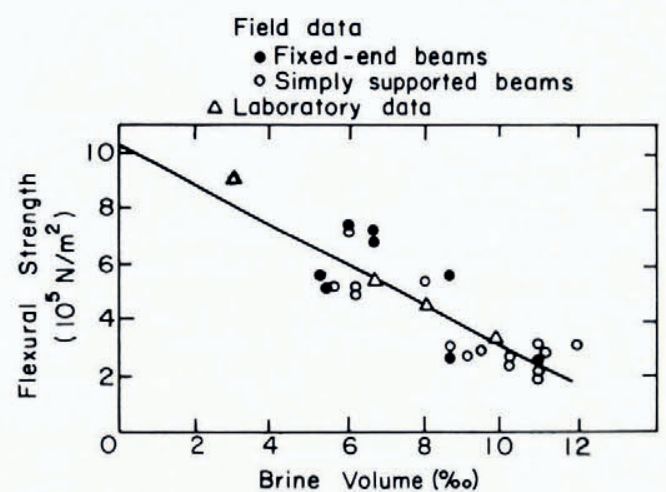

Fig. Io. Flexural strength as measured by fixed-end and simply supported beams versus brine volume (Dykins, 197I).

Strength tests with different stress- or strain-rates have shown quite contradictory results. Tabata and others $(1967)$ have tested cantilever beams of sea ice-even recently in the Gulf of Bothnia (Tabata and others, I975) - at stress rates up to about $3 \times 10^{5} \mathrm{~N} / \mathrm{m}^{2} \mathrm{~s}$. They found a considerable increase of the flexural strength of sea ice with increasing stress rates. However, if the inertial force associated with the displacement of the water during rapidly performed tests is eliminated (Määtänen, I976), the flexural strength of sea ice appears to be almost independent of the stress rate.

Even though the flexural strength is not a basic material property, it is relatively easy to obtain, and therefore it is commonly used as an indicator of the strength of ice. Our present knowledge of the flexural behavior of sea ice, however, is not sufficient for us to obtain reproducible and consistent results. Questions such as the size effect, the failure mechanism, and the shear involvement in the failure of beams, remain unresolved.

\section{Shear strength}

Only a small number of shear-strength tests have been carried out and reported. In fact, many tests described as "shear" are actually the result of mixed-mode failures as in punch tests. Indeed, it is extremely difficult to obtain pure shear strengths. The best sets of sheartest data available are those of Paige and Lee (1967) and of Dykins (197r). Paige and Lee's ( 1967 ) results show similar trends with brine volume changes (Fig. I I) as do in-situ cantilever beam tests (Fig. 9). Also the absolute value of the shear strength is in the range of observed flexural and tensile strengths (with tension applied parallel to the growth direction). Dykins (I97I) found the shear strength of sea ice to be not appreciably affected by different crystal orientations. This indicates again that not only are grain boundaries and the basal planes of ice crystals lines of easy slip but that the same is also true of planes within the substructure where brine pockets and imperfections are lined up. 


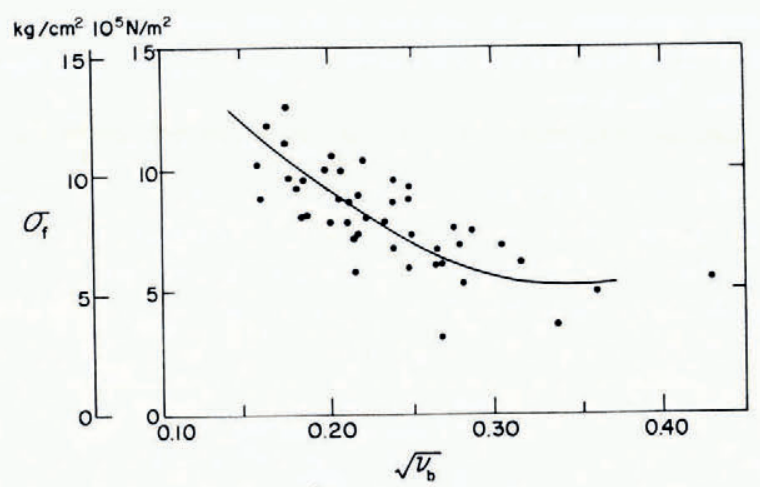

Fig. II. Shear strength as a function of the square root of brine volume (Paige and Lee, 1967).

Even though the few results available indicate a strong dependency of the shear strength on the load or strain-rate, this effect cannot yet be quantified. This is an area requiring more thorough investigations.

Some contradictory results on the effect of temperature on shear strength have been reported by Kantona and Vaudrey (1973). On the one hand, shear strength increased significantly in a similar fashion to other strength results when the temperature was lowered from -2 to $-10^{\circ} \mathrm{C}$. On the other hand, the shear strength was lower at $-10^{\circ} \mathrm{C}$ than at $-4{ }^{\circ} \mathrm{C}$ and greater at $-20^{\circ} \mathrm{C}$ than at $-27^{\circ} \mathrm{C}$. This last result is probably incorrect, but it is mentioned here in order to show the gaps and to stimulate further investigations, especially on shear strength, which has been widely disregarded in the past.

\section{Suggestions for further study}

Although our knowledge of the relationships between the various strength properties of sea ice and its brine volume is fairly satisfactory, additional studies at high brine volumes would be most useful. In addition, uncertainties remain regarding the effect on strength of the strain- or stress-rate, of the sample size, of the loading direction in relation to the crystal orientation, and of the crystallization of solid salts. Also the behavior of sea ice under two- and three-dimensional stress states has not been investigated even though such stress states actually occur in many applied problems.

\section{Elastic modulus}

There has not, as yet, been an adequate theoretical treatment of the variation in the elastic modulus of sea ice with brine volume and crystal orientation based on a realistic model of the arrangement of inclusions in sea ice. Even so, current experimental observations are in general agreement with theoretical predictions for materials with a random distribution of pores in that the variation in $E$ with the volume fraction of pores is to a good approximation linear in the porosity range o to $10 \%$ (Coble and Kingery, 1956; Buch and Goldschmidt, 1970), which is the range in which sea ice has primarily been studied.

\section{Dynamic measurements}

By dynamic measurements of the elastic modulus $E$ we mean values determined by either the rate of propagation of vibrations in the ice or by exciting natural (resonant) frequencies of different types of vibrations. The displacements in such measurements are extremely small and, for many purposes, anelastic effects can be neglected. Therefore, dynamic measurements 
of $E$ tend to be quite reproducible when compared with $E$ values determined from typical mechanical tests.

In-situ seismic determinations of $E$ for natural sea ice have been reviewed by Weeks and Assur (1967). More recent results have been reported by Kohnen (1972). E was found to vary from ( 1.7 to 5.7$) \times 10^{9} \mathrm{~N} / \mathrm{m}^{2}$ when measured by flexural waves and ( 1.7 to 9.1$) \times \mathrm{I}^{9}$ $\mathrm{N} / \mathrm{m}^{2}$ when determined by in-situ body-wave velocities. The $E$ values when measured on similar ice, are invariably larger when determined by body waves. This is reasonable inasmuch as the flexural-wave velocity is controlled by the overall properties of the ice sheet while the body-wave velocity is controlled by the high-velocity channel in the usually colder and stiffer upper portion of the ice. Pronounced changes in $E$ are noted throughout the year with high values occurring in winter (cold, low brine volumes) and low values in the summer (warm, high brine volumes). Detailed studies of the relation between $E$ and brine volume have been made by Anderson (1958[b]) and Brown and Howick (1958). Both test series show a pure-ice intercept at zero brine volume of (9 to ro) $\times 10^{9} \mathrm{~N} / \mathrm{m}^{2}$ and a pronounced decrease in $E$ as $\nu_{\mathrm{b}}$ increases. The Anderson's results are shown in Figure 12.

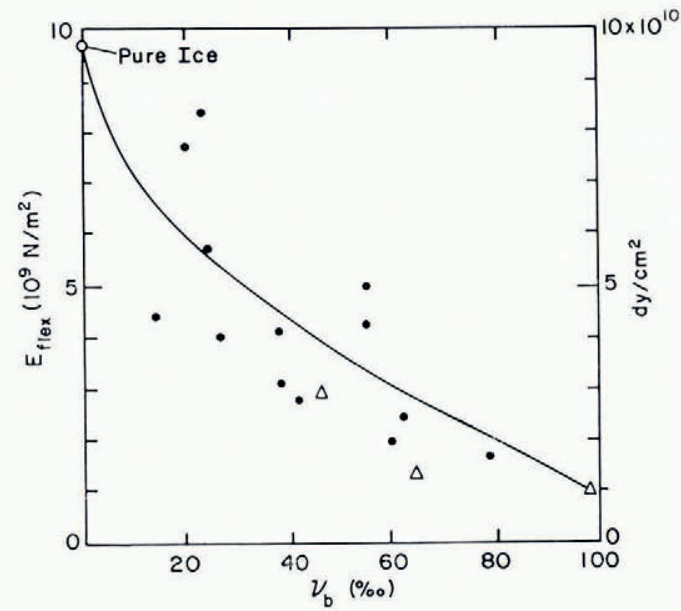

Fig. 12. Elastic modulus of sea ice as determined by seismic techniques versus brine volume (Anderson, $\left.195^{8}[b]\right)$. The three triangular points are the results of static tests performed by Dykins (I97I).

The remainder of the dynamic determinations of $E$ were made on small specimens which had been removed from the ice sheet. A representative series of tests performed by Langleben and Pounder (1963) is shown in Figure 13. $E$ values at zero brine volume are characteristically found to be (9 to 10$) \times 10^{9} \mathrm{~N} / \mathrm{m}^{2}$, in good agreement with the seismic determinations. The decrease in $E$ with increasing $\nu_{\mathrm{b}}$ appears to be linear within the range of brine volumes studied. Recent studies suggest that at $\nu_{\mathrm{b}}$ values greater than o. I the value of $E$ decreases more slowly becoming a weak function of $\nu_{\mathrm{b}}$ at $\nu_{\mathrm{b}}$ values in excess of $0 . \mathrm{I}_{5}$ (Slesarenko and Frolov, [1974]). This is in general agreement with theoretical predictions (Coble and Kingery, 1956; Hashin, 1970). However in these predictions, appreciable deviations from a linear relation do not occur until porosity values become larger than o.2.

\section{Static measurements}

Static measurements of $E$ are much more variable and difficult to interpret than are dynamic measurements because of the visco-elastic behavior of ice when subjected to significant stresses for finite time periods. Nevertheless static measurements are extremely important 


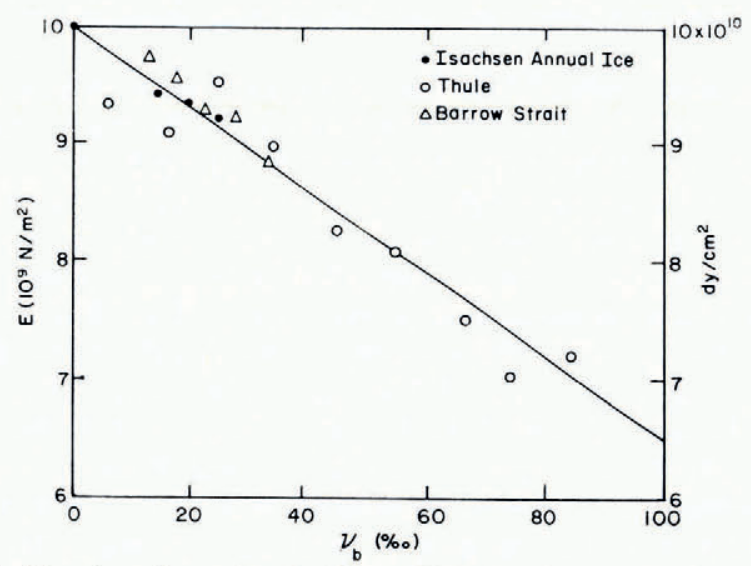

Fig. 13. Elastic modulus of cold arctic sea ice as determined by small specimen tests versus brine volume (Langleben and Pounder I963).

as they are required in the consideration of problems such as ice forces on structures and vessels and bearing-capacity calculations.

The most extensive study of the static modulus of sea ice is by Dykins (I97 I) who tested small beams in bending. His stress-strain curves which were obtained at stress rates of $2.6 \times 10^{5} \mathrm{~N} / \mathrm{m}^{2} \mathrm{~s}$ were quite linear. The plots of $E$ versus temperature are suggestive of discontinuities at the temperatures where $\mathrm{Na}_{2} \mathrm{SO}_{4} \cdot \mathrm{IOH}_{2} \mathrm{O}$ and $\mathrm{NaCl} \cdot{ }_{2} \mathrm{H}_{2} \mathrm{O}$ precipitate $\left(-8.7^{\circ} \mathrm{C}\right.$ and $-22.8^{\circ} \mathrm{C}$ respectively). However, testing is not sufficiently detailed to establish this effect clearly. When $E$ was plotted against $\nu_{\mathrm{b}}$, the values indicated by the triangles in Figure 12 were obtained. It is encouraging to note that the values obtained by static measurements are in general agreement with the "seismic" values obtained by Anderson.

In 1967 Weeks and Assur ( 1967 ) proposed the following relationships between the elastic modulus $E$, the flexural strength $\sigma_{\mathrm{f}}$, and the brine volume $\nu_{\mathrm{b}}$ in connection with the formulation of a physical model of sea ice,

$$
\begin{aligned}
& \frac{\sigma_{\mathrm{f}}}{\sigma_{0}}=\left(\mathrm{I}-\nu_{\mathrm{b}^{\frac{1}{2}}}\right)^{2}, \\
& \frac{E}{E_{0}}=\left(\mathrm{I}-\nu_{\mathbf{b}^{\frac{1}{2}}}\right)^{4} .
\end{aligned}
$$

By combining both equations we obtain

$$
\frac{\sigma_{\mathrm{P}}}{\sigma_{0}}=\left[\mathrm{I}-\left\{\mathrm{I}-\left(E / E_{0}\right)^{\frac{1}{2}}\right\}^{\frac{1}{2}}\right]^{2} .
$$

Laboratory tests on the flexural strength and elasticity of saline ice as determined in flexure have been carried out by Schwarz (1975). The results plotted in Figure I4 support the theoretically developed relationship between $E, \sigma_{\mathrm{f}}$ and $\nu_{\mathrm{b}}$. These results are quite important to investigators working on the physical modeling of ice problems in which it is desirable to keep the ratio $E / \sigma$ the same in both the model ice and the natural ice. As indicated in Figure I4, for high brine contents the elasticity of saline ice is too small compared with its strength. Current measurements of the $E / \sigma$ ratio of natural sea ice give values varying between 2 ooo to 5000 as determined in flexure and tension to as low as 330 as determined in compression (Schwarz, I975; Johnson, [1972]). 


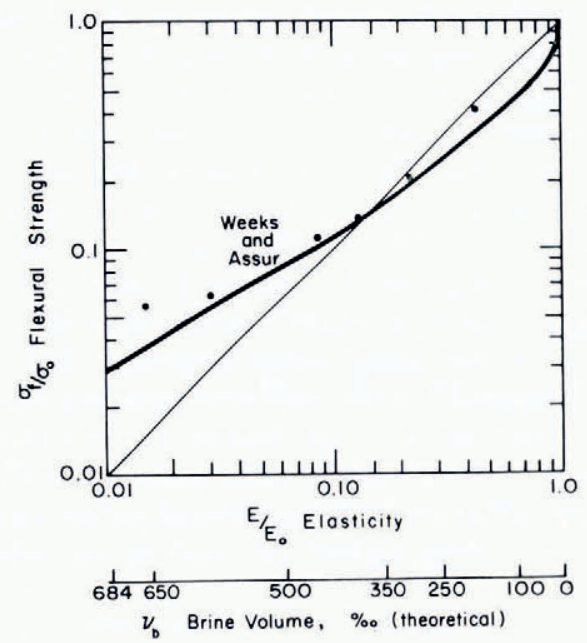

Fig. 14. Normalized strength versus normalized elastic modulus for saline model ice (Schwarz, 1975).

\section{Poisson's ratio}

In discussing Poisson's ratio, i.e. the ratio between the strain in two directions perpendicular to each other in simple tension, it is important to distinguish between the dynamic and the static method. The only data presently bearing on the variation of Poisson's ratio $\mu$ with sea-ice structure and state is that of Lin'kov (1958) based on in-situ seismic observations at Kap Shmit, Siberia. From these observations, Weeks and Assur (1967) proposed a formula which expresses $\mu$ as an extremely weak function of ice temperature. Presumably, the prime functional relation will prove to be between $\mu$ and $\nu_{\mathrm{b}}{ }^{\frac{1}{2}}$. The value of $\mu$ would also be expected to vary with the structural orientation of the ice and the loading conditions (assuming that the ice is to a large extent permeable). Inasmuch as studies of other materials indicate that $\mu$ shows only slight changes $(<10 \%$ ) over porosity ranges of up to $30 \%$ (Buch and Goldschmidt, I970), for most engineering purposes $\mu$ can be considered constant with a value of $\frac{1}{3}$. Also a detailed examination of the theoretical effects of the vertical variation of $\mu$ through a floating ice sheet on the mechanical response of the sheet (Hutter, 1975) has indicated that for most real problems it is not necessary to consider the variation of $\mu$.

Although the above may be true for elastic deformation, it is quite important to know the ratio of the strain in different directions if the ice deforms visco-elastically or plastically. Static measurements of the strain ratio have been carried out by Hirayama and others (1974) by freezing strain gages along the three principal strain directions into a fresh ice cover in front of a vertical pile. As long as the ice deformation remained elastic, Poisson's ratio was 0.3. But when the ice was deformed plastically the ratio $\epsilon_{z}: \epsilon_{x}$ ( $z$ being the vertical direction, $x$ the direction of advance and $y$ the lateral direction) increased to about 0.8 due to the lateral confinement of the ice cover $\left(\epsilon_{y} \approx 0\right)$. This caused the ice cover to fail by cleavage as a result of tensile strain in the $z$-direction. Similar investigations on the strain ratio in different directions are desirable for sea ice in respect to stress state, temperature, salinity, and loading rate.

\section{Friction AND ADHESION}

The frictional and adhesive characteristics of sea ice are extremely important in a wide variety of applied problems. For instance, current thinking on the physics of icebreaking by ships suggests that in continuous-mode icebreaking the dominant aspect of the ice resistance is 
related to forces associated with the buoyancy of the ice (Lewis and Edwards, 1971). These include the frictional forces between the broken ice and the hull (forces associated with the initial breaking of the ice appear to be comparatively small). Also, as we have discussed earlier, current testing indicates that ice forces measured during studies of ice and piles are as much as $50 \%$ higher if the ice is allowed to bond to the pile (Croasdale, 1974). In fact, ice-ice and ice-metal friction and ice-metal adhesion are components of a proper analysis of almost every problem concerned with the differential motion of sea ice and structures. Therefore, the paucity of information on this subject is rather surprising.

Table II summarizes the currently available data. There obviously is considerable scatter and the data are of use only for providing rough estimates. It is recommended that anyone using these data study the details of how the different data sets were obtained before applying them to specific problems. Some general conclusions can, however, be drawn from the tests. These are: static friction coefficients are appreciably larger than dynamic coefficients reaching values of up to 0.7 and are also relatively independent of surface pressure; dynamic coefficients first decrease rapidly with increasing surface pressure up to values of roughly $5000 \mathrm{~N} / \mathrm{m}^{2}$,

TABle II. Friction coefficients

Investigator
Arnol'd-Alyab'yev ( $\left.193^{8}\right)$
Jansson (1956)
Milano (1962)
Ryvlin and Petrov (1965)
Enkvist (1972)

Finke (1972)

Airaksinen (1974)

Grothues-Spork (1974)

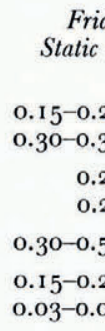

Friction coefficient

Kinetic

0. $100-0.200$

0.200

0.100-0.150

0.200

$0.100-0.200$

$0.15-0.20$
$0.03-0.04$

$$
\begin{array}{r}
0.025-0.045 \\
0.110 \\
0.090-0.190 \\
0.310 \\
0.030-0.100 \\
0.140
\end{array}
$$

$0.045^{-0.065}$

$0.40-0.70$

$0.070-0.25^{\circ}$

$0.30-0.50$

o. $120-0.230$

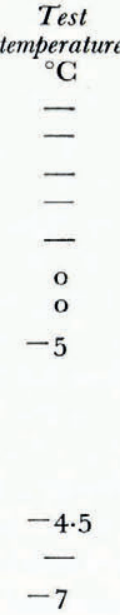

while at higher surface pressures coefficients are generally constant with values varying between 0.04 and $0.1 \mathrm{I}$; dynamic coefficients are practically independent of velocity (even on wet ice); dry snow increases sliding friction to about four times the value for dry ice, and wet snow produces essentially the same values as dry snowless ice.

There do not appear to be any detailed studies of the adhesion of sea ice to surfaces. This is not too surprising in that if the adhesion of pure ice to clean surfaces is difficult to understand then the adhesion of sea ice to dirty surfaces can hardly be a readily tractable problem. It is reasonable to assume that the adhesive strength will prove to be highly dependent on the brine volume in the ice although preliminary attempts to obtain a correlation with ice salinity have shown that the relation is not simple (Ryvlin and Petrov, 1965). Additional work on this subject is badly needed.

\section{THERMAL PROPERTIES}

From an engineering point of view our knowledge of the thermal characteristics of sea ice is in a fairly developed state. The classic reference on this subject is Malmgren (1927). However his studies have recently been expanded by several different authors; specifically 
Anderson (1960), Schwerdtfeger (1963) and Ono (1966, I967, I968). Here by the thermal properties of sea ice we particularly refer to the parameters comprising the thermal diffusivity term in the diffusion equation; i.e. the specific heat, the thermal conductivity, and the density. However we will also discuss the latent heat and the heat required to melt sea ice that is initially at an arbitrary temperature. All of these show properties fairly complex dependence on both the temperature and the composition while the thermal conductivity also requires information on the geometric distribution of all the components.

\section{Specific heat}

The specific heat of sea ice primarily depends upon the amount of water changing state during a temperature change as well as on the specific heats of pure water, ice, and solid salts making up the sea ice. The pertinent equations can be found in either Schwertdfeger $(1963)$ or Ono $(1967)$. Both authors tabulate calculated values of the specific heat in the salinity and temperature ranges of o to $10 \%,-2{ }^{\circ} \mathrm{C}$ to $-23^{\circ} \mathrm{C}$ (Schwerdtfeger, 1963) and

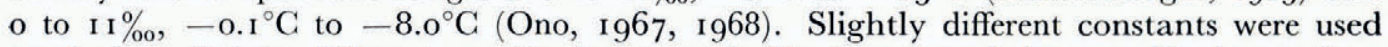
producing slightly different specific heats, with Ono's values being usually lower than Schwerdtfeger's (the maximum difference of $4.4 \%$ occurs at high salinities and temperatures). Schwerdtfeger's values have recently been compared against the results of a series of determinations of the specific heat of artificial sea ice performed by Dixit and Pounder (1975). The agreement was very good (within $4.5 \%$ ) with the experimental value commonly being slightly larger than the theoretical. An earlier comparative study using specific heats of real sea ice on $\mathrm{SP}-4$ versus theoretical values as calculated by Malmgren can be found in Nazintsev (1959).

\section{Latent heat}

In pure materials the latent heat is a well-defined parameter implying a release or absorption of heat at the constant temperature specified by the particular phase change involved. In sea ice such a "discontinuous" process does not occur and the heat input (or output) is associated with a continuous change in sample temperature. Nevertheless the amount of pure ice formed from a unit mass of sea ice at the freezing temperature can be ascertained and the heat associated with this ice calculated. Values of this "latent heat" for ice salinities of up to $8 \%$ are calculated by Schwerdtfeger (1963). Perhaps more important are the values of heat required to completely melt isolated specimens of sea ice. Calculated values of this parameter can be found in Schwerdtfeger (I963) and in Ono (I968). A particularly useful parameter is the amount of heat required to change the temperature of I gram of sea ice from one arbitrary temperature to another. Nomographs allowing this quantity to be rapidly determined are given by Untersteiner (1964) and by Ono (rg68).

\section{Thermal conductivity}

The thermal conductivity $k$ of sea ice is a particularly interesting property in that it is dependent on the geometric arrangement of the phases involved as well as their relative volumes and conductivities. Sea ice of course is a mixture of ice, brine, and air, and, at temperatures below $-8.2^{\circ} \mathrm{C}$, solid crystals of salt. Anderson (1958[a], i96o) calculated $k$ for several different geometries of ice and brine: parallel layers of brine and ice with conductivity measured (a) normal to the layers and (b) parallel to the layers, and (c) parallel brine cylinders spaced according to thin-section measurements with conductivity measured parallel to the axis of the cylinders and (d) spherical brine pockets. Options (b) and (c) which are the most realistic gave very similar results. However, Anderson did not consider the presence of gas in the sea ice. This important factor was included in the calculations of Schwerdtfeger 
(1963) and Ono (1968) but in slightly different ways. Schwerdtfeger considered the gas phase to be uniformly distributed in spherical inclusions within the ice only and then included the brine as a series of vertical cylinders alined parallel to the direction of heat flow. Ono considered the air bubbles to be uniformly dispersed in both the ice and the brine with the brine being arranged in layers oriented parallel to the direction of heat flow. Ono's results, which are based on a slightly more realistic model, are preferable, although either set of values should be adequate for most purposes.

Both Schwerdtfeger's and Ono's calculations only go down to $-8^{\circ} \mathrm{C}$ (just before the first solid salt, $\mathrm{Na}_{2} \mathrm{SO}_{4} \cdot \mathrm{IOH}_{2} \mathrm{O}$, crystallizes out of the brine). Calculations of the values of $k$ at lower temperatures have not been carried out because thermal conductivities of the different hydrated solid salts are not available. Fortunately this is not a major problem inasmuch as at temperatures near $-8^{\circ} \mathrm{C}$, the $k$ of air-free sea ice, which rarely would have a salinity of more than $10 \%$, is within roughly $\mathrm{I} \%$ of the $k$ of air-free pure ice with the difference decreasing as the temperature drops.

Comparisons between the calculated values of $k$ and values measured from natural sea ice have been made by several different authors, notably Schwerdtfeger (1963), Lewis (1967) and Weller (1968). In all cases good agreement was obtained. This was particularly true in the study by Lewis, which is the most extensive comparative investigation yet published.

We feel that the short-comings in any such comparisons are not with the details of how $k$ is calculated but with the fact that only rarely is the volume of gas entrapped in the ice measured precisely enough (it is rarely measured at all) to allow really first-class comparisons to be made between theoretical and observed values. Although this might not prove to be a major problem in the first-year ice upon which these published comparisons have been made, there is every reason to believe that gas measurements would be essential to any comparative study using multi-year ice. It is also reasonable to assume that the processes of brine migration within the ice sheet should result in the vertical transfer of appreciable amounts of heat. The effects of such processes on altering the observed values of $k$ have not, to our knowledge, been seriously examined.

\section{Density}

Information on the variation of the theoretical density of gas-free sea ice can be found in Malmgren (1927), Zubov ( 1945 ) and Anderson ( 1960 ) with values ranging from 920 to $95^{\circ}$ $\mathrm{kg} / \mathrm{m}^{3}$ depending on the temperature and salinity of the ice. Because of gas entrapped in natural sea ice, real densities are invariably lower than these calculated values. Calculations of sea-ice density incorporating the effects of gas inclusions are given by Schwerdtfeger (1963) and Ono (1968). As Schwerdtfeger points out, in density as in thermal conductivity, there are two interesting asymptotic tendencies in that at temperatures near the melting point the values of these parameters are largely controlled by the amount of liquid brine present while at low temperatures it is the volume of entrapped air that is the important factor.

In first-year ice densities of 910 to $920 \mathrm{~kg} / \mathrm{m}^{3}$ are common although values as low as 840 $\mathrm{kg} / \mathrm{m}^{3}$ have been observed during the early part of melt season (Weeks and Lee, 1958). Detailed ice-profile information collected on the $197 \mathrm{I}$ and 1972 AIDJEX stations gave average multi-year ice densities of 910 and $915 \mathrm{~kg} / \mathrm{m}^{3}$ (Hibler and others, 1972 ; Ackley and others, 1974). The data collected in 1972 indicated that the higher the freeboard of the (multi-year) ice, the lower the average ice density as given by the empirical equation

$$
\rho=-\mathrm{r} 94 f+974,
$$

where $\rho$ is the ice density (in $\mathrm{kg} / \mathrm{m}^{3}$ ) and $f$ the freeboard in metres. For most purposes, unless detailed information on the actual density of a specific piece of sea ice is required (which would probably require direct field measurements), a value of $910 \mathrm{~kg} / \mathrm{m}^{3}$ should serve as a reasonable estimate. 


\section{Thermal diffusivity}

The parameter that actually enters the differential equation for heat transfer in an isotropic medium is the thermal diffusivity $K \equiv k / \rho c$ where $k$ is the thermal conductivity, $\rho$ is the densi.y, and $c$ is the specific heat. The temperature dependence of $K$ is more than the temperature dependence of the three parameters that comprise it in that as temperature increases, $k$ decreases while both $\rho$ and $c$ increase. A graph showing the calculated variation in $K$ in the temperature range $o$ to $-8^{\circ} \mathrm{C}$ and the salinity range o to $12 \%$ is given by Ono (1968). Comparisons between observed and calculated values of $K$ have been made by both Weller (1968) and Ono (1968) with rough agreement. One striking result of Weller's study was the obvious importance of the effect of direct radiation on determining the temperature in such a transparent medium as sea ice. If it becomes necessary to take the absorbtion of short-wave radiation into account, observed values for the extinction coefficient fortunately show general agreement: $0.013 \mathrm{~cm}^{-1}$ (Bunt, I960), $0.01 \mathrm{I} \mathrm{cm}^{-1}$ (Thomas, I963), $0.013 \mathrm{~cm}^{-1}$ (Untersteiner, 196r) and o.or $2 \mathrm{~cm}^{-1}$ (Weller, I968).

\section{Electromagnetic PROPERTIES}

The variations in the electromagnetic properties of sea ice are both complex and poorly understood and have only recently been studied in detail. As we mentioned earlier these properties are of prime importance in remote sensing where a thorough understanding of the interactions between electromagnetic radiation and sea ice is desirable for both interpreting field observations and designing new instruments.

Many of the electrical measurements on sea ice have been performed on "artificial" samples that were prepared in the laboratory. Therefore it is interesting to start our discussion with observations on the d.c. resistivity of sea ice, a parameter that is commonly measured in the field on natural ice sheets using a Wenner array of electrodes. McNeill and Hoekstra (I973) and Kohnen ([1976]) obtained resistivity values of between 40 to $120 \Omega \mathrm{m}$ in representative first-year ice when small electrode spacings were used. Smaller values (6 to $32 \Omega \mathrm{m}$ ) were observed by Fujino (1960) but the ice that he studied was thinner, warmer and more saline. As the electrode spacings increased, the resistivity values dropped rapidly, approaching a value of $0.4 \Omega \mathrm{m}$ which is the resistivity of cold sea-water. As might be expected, attempts to determine ice thickness via the use of such data have been unsuccessful. The difficulty is that the models used in the analysis assume not only that we are dealing with a layered system (which, of course, we are) but also that the individual layers are electrically homogeneous. That this last assumption is far from the case can be seen in Figure 15 which presents resistivity values determined at $18 \mathrm{kHz}$ by McNeill and Hoekstra (1973) on cores from both first- and multi-year ice. The first-year ice values vary from $6_{5} \Omega \mathrm{m}$ at the upper surface to roughly $3 \Omega \mathrm{m}$ near the bottom at $1.40 \mathrm{~m}$ and are in reasonable agreement with the d.c. resistivities. Multi-year ice shows much larger variations (over three powers of ten) with values of 20 ooo $\Omega \mathrm{m}$ for the cold low-salinity surface ice and $20 \Omega \mathrm{m}$ for the warmer more saline ice at the bottom of the sheet. The break in the multi-year resistivity profile corresponds to a break in the salinity profile caused by the presence in the lower portion of the ice sheet of more saline ice formed during the latest ice-growth season. Temperature and salinity profiles can be found in the original paper.

One rather surprising result of both the resistivity studies of McNeill and Hoekstra and of Kohnen is that when the electrode array was moved from site to site on the ice using a fixed electrode spacing and a similar lateral shift for each move, the apparent resistivity showed large fluctuations of a factor of four (see Fig. 16) even though the first-year ice in both areas was specifically selected for its apparent lateral homogeneity and each measurement integrates over a considerable volume of ice. These are rather sobering results, because if such variations 


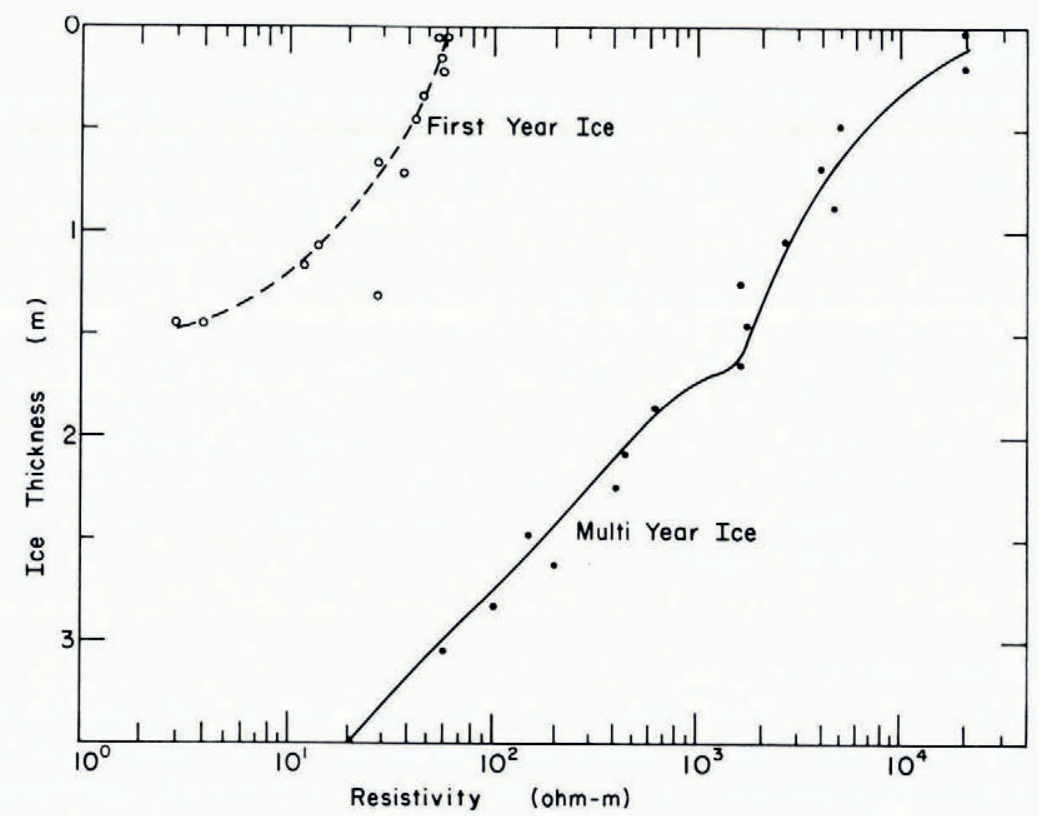

Fig. 15. Vertical resistivity profiles of typical first year and multi-year sea ice measured at $18.6 \mathrm{kHz}$ (McNeill and Hoekstra, 1973).

prove to be commonplace in otherwise laterally uniform sea ice, they obviously must be considered in the development of remote-sensing systems designed to measure ice characteristics. These resistivity fluctuations must at least in part be due to erratic salinity variations. It has been known for some time (Weeks and Lee, I962) that there are significant random lateral variations in salinity measured at identical depths in the ice. Even so, resistivity variations of such magnitude are surprising. Variations in multi-year ice would be expected to be even larger.

Studies of the dielectric characteristics of sea ice that cover a wide range of frequencies below roo $\mathrm{MHz}$ and/or temperatures are those of Wentworth and Cohn (1964), o. I to $30 \mathrm{MHz},-5$ to $-40^{\circ} \mathrm{C}$; Fujino ( $1967[\mathrm{a}],[\mathrm{b}]$ ), $100 \mathrm{~Hz}$ to $50 \mathrm{kHz},-5$ to $-70^{\circ} \mathrm{C}$; Addison (1969), $20 \mathrm{~Hz}$ to $100 \mathrm{MHz},-12.5$ to $-35^{\circ} \mathrm{C}$; Khokhlov (1970), 100 $\mathrm{Hz}$ to $\mathrm{I} \mathrm{MHz},-5$ to

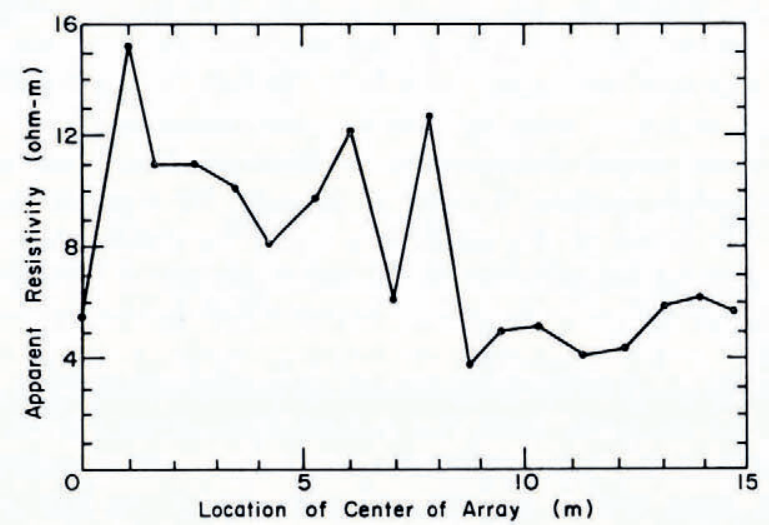

Fig. 16 . The apparent resistivity of first year ice of uniform thickness determined in a linear traverse with a Wenner array having an electrode spacing of $0.92 \mathrm{~m}$ (McNeill and Hoekstra, 1973). 
$-30^{\circ} \mathrm{C}$; and Addison ( 1975 ), $\mathrm{I} \mathrm{kHz},-25$ to $-150^{\circ} \mathrm{C}$. The studies of the temperature dependence of the dielectric constant, particularly that by Addison (1975) have proven to be quite informative in that the temperatures at which the various solid salts crystallize from the brine can be identified. Also the data indicates the presence of brine within the ice until much lower temperatures $\left(-70\right.$ to $\left.-75^{\circ} \mathrm{C}\right)$ than suggested by earlier studies. Finally, although there is evidence for fluoride doping in the ice phase of sea ice, there appears to be no strong reason for postulating substitutional chloride.

The measurements of the frequency dependence can be considered in three parts (Fig. I 7 ). In the low frequency range both the real and imaginary parts of the dielectric constant $\left(\epsilon^{\prime}\right.$ and $\left.\epsilon^{\prime \prime}\right)$ show very large values ( $\mathrm{I}^{4}$ to $\mathrm{IO}^{7}$ ) with $\epsilon^{\prime \prime}$ values being larger than $\epsilon^{\prime}$ up to at least $\mathrm{I} \mathrm{MHz}$. The loss tangent $(\tan \delta)$ is usually near so indicating that sea ice is a rather lossy material in this range. As frequency increases the values of $\epsilon^{\prime}$ decrease almost inversely up to I $\mathrm{MHz}$. Addison (1970) suggests that in this frequency range the observed electrical properties are
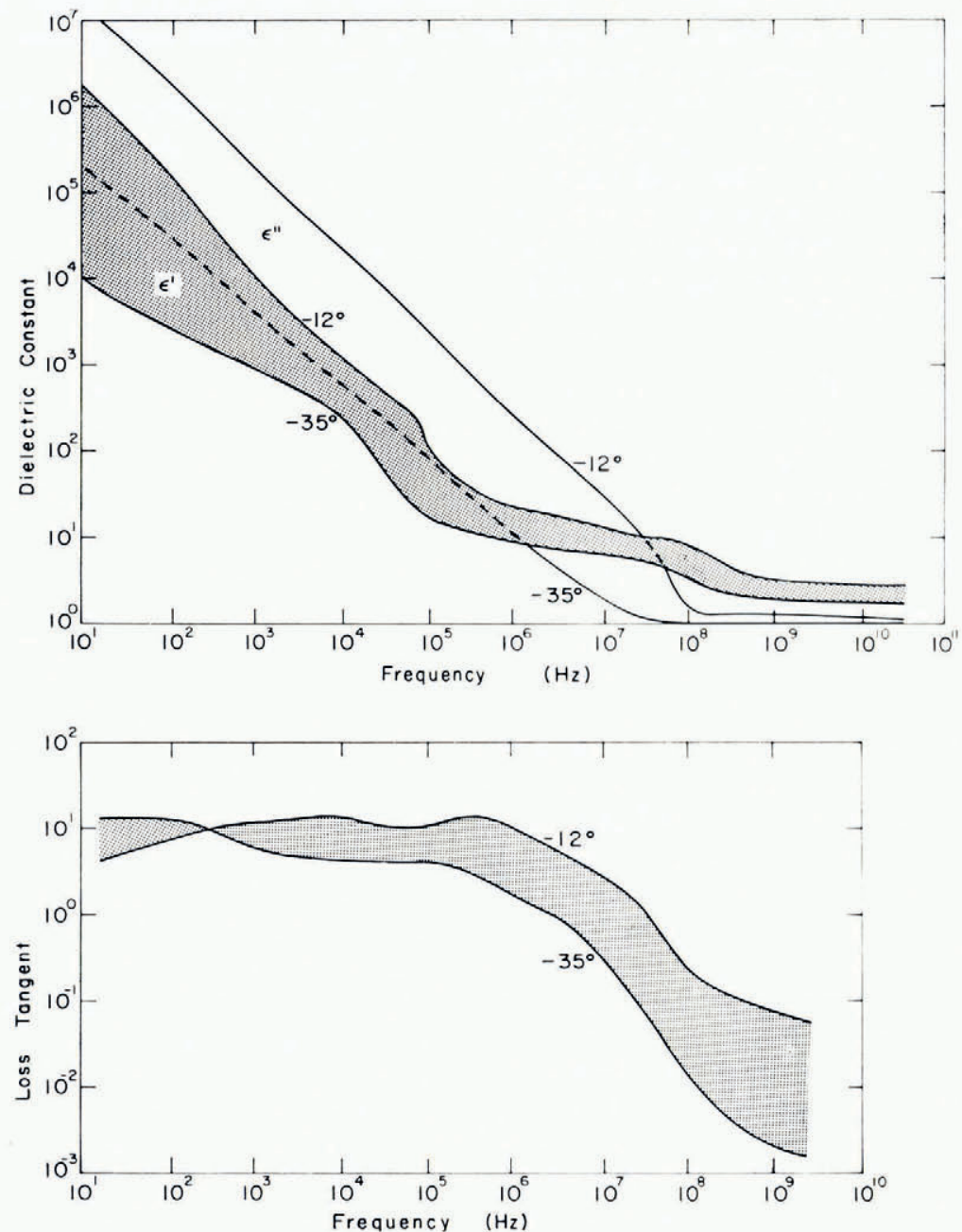

Fig. 17. Schematic diagram showing the variation in the real $\left(\epsilon^{\prime}\right)$ and imaginary $\left(\epsilon^{\prime \prime}\right)$ components of the dielectric constant and the loss tangent $(\tan \delta)$ as a function of frequency; based primarily on results of Addison (1969) and Vant (unpublished). 
principally controlled by the migration of ions in the irregular inter-connected brine channels that link the electrodes. The experimental observations (Fujino, I967[a], [b]) suggest that at low temperatures when the brine channels are no longer interconnected, this mechanism becomes ineffective.

In the mid-frequency range ( 10 to $100 \mathrm{kHz}$ ), curves of $\epsilon^{\prime}$ versus temperature show a downward concavity and two maxima are observed in many of the $\tan \delta$ curves. The suggested but tentative explanation is Debye dispersion of the ice protons with a somewhat shortened relaxation time. Similar reduced relaxation times have been observed in fluoride-doped ices.

At frequencies above I $\mathrm{MHz}$ the curves for $\epsilon^{\prime}$ flatten out and the $\epsilon^{\prime \prime}$ curves also decrease less rapidly (above Io $\mathrm{MHz}$ ). There is also a gradual decrease in $\tan \delta$ from $\mathrm{I} \mathrm{MHz}$ to Io $\mathrm{MHz}$ where it usually has values near or below unity. The dispersion in this range is believed to be the result of interfacial polarization arising from the presence of brine inclusions. As such, it should be possible to model the variations in $\epsilon$ in terms of a mixed dielectric model based on the volume of brine present in the ice. That this would be a profitable approach was shown by Weeks (r968) who took the Wentworth and Cohn data at $3 \mathrm{MHz}$, grouped the values according to structural ice type (normal sea ice, frozen slush) and plotted $\epsilon^{\prime}$ versus $\nu_{\mathrm{b}}$. The result was two straight lines with distinctly different slopes.

The dielectric properties of sea ice at higher frequencies have been studied by Hoekstra and Cappillino (I97I), o. I to $24 \mathrm{GHz}$; Sackinger and Byrd (I972), 26 to $40 \mathrm{GHz}$; Vant and others (I974), ro and $35 \mathrm{GHz}$, and Vant (unpublished), Ioo $\mathrm{MHz}$ to $40 \mathrm{GHz}$. Values of $\epsilon^{\prime}$ and $\epsilon^{\prime \prime}$ range between 2.5 and 6.0 and 0.0 and 1.9 respectively. In correlating their data Hoekstra and Cappillino used with considerable success over a wide range of brine volumes a dielectric mixing formula proposed by DeLoor (unpublished). The relation was

$$
\epsilon_{\mathrm{s}}{ }^{\prime}=\epsilon_{\mathrm{i}}{ }^{\prime}\left(\mathrm{I}-3 \nu_{\mathrm{b}}\right)
$$

where $\epsilon_{\mathrm{s}}{ }^{\prime}$ and $\epsilon_{\mathrm{i}}{ }^{\prime}$ are the real dielectric constants of sea ice and pure ice respectively and $\nu_{\mathrm{b}}$ is the relative volume of brine. The actual values obtained by Hoekstra and Cappillino are suspect because the structure of the artificial sea ice that they produced by flash freezing was probably not similar to the structure of natural sea ice. The model assumes that the brine inclusions are spherical. Vant and others (1974) also used this relation to correlate their data and obtained good results for frazil sea ice (correlation coefficient $r=0.8 \mathrm{I}$ ) and for columnar sea ice $(r=0.90)$. For multi-year ice the correlation was lower $(r=0.57)$. They also used another model based on Wiener's dielectric mixing formula which gave a higher correlation $(r=0.723)$ for multi-year ice and slightly lower correlations $(r=0.76$ and 0.85$)$ for frazil and columnar ice. This work has recently been greatly expanded by Vant (unpublished) who has also successfully used empirical dielectric mixing equations to predict the dielectric behavior of sea ice at any of the several frequencies he studied. He has also attempted to develop a general theoretical model that works over a wide frequency range. At present the theoretical and observed values are in reasonable argeement for first-year ice. The fact that results for multi-year ice show less than good agreement is believed to be the result of large variations in the amount of entrapped gas in the ice as well as of the very low overall salinities characteristic of such ice. A detailed discussion of Vant's results is beyond the scope of this paper. However, his results are particularly encouraging in that the dielectric loss of sea ice at $\mathrm{I} \mathrm{GHz}$ is a factor of 5 less than initially reported by Hoekstra and Cappillino. Figure $\mathrm{I} 8$ shows the trends of the frequency dependence of both the attenuation (dielectric loss) in $\mathrm{dB} / \mathrm{m}$ and the attenuation distance (skin depth) in meters for first-year sea ice based on the experimental results of Addison (1969) and Vant (unpublished). This figure is very informative in explaining the difficulty in developing an operational system for remotely determining sea-ice thickness: at low frequencies the penetration is good (low attenuation) but the resolution is poor (the wave length $\lambda \gg$ ice thickness $h$ ) while at high frequencies the resolution is good $(h \gg \lambda)$ but the penetration is negligible. The figure suggests that the best 
compromise between these two conflicting requirements would be found in the frequency range between io $\mathrm{MHz}$ and I GHz. In fact the Geophysical Survey Systems Inc. VHF impulse radar system which has proven to be effective in profiling sea ice (Campbell and Orange, 1974; Kovacs, in press) has a center frequency in this range (100 MHz). Soviet investigators have also had success in profiling sea ice when working in this frequency range (Bogorodskiy and Tripol'nikov, r975; Finkel'shteyn and others, 1975).

Finally we would like to note that Campbell and Orange (1974) while using the abovementioned pulsed radar system to measure the thickness of sea ice have noted a marked change in the amplitude of the return from a vertically polarized signal when the antenna was rotated. This anisotropy has been observed in both first-year and multi-year ice with all first-year ice showing the effect and some showing it very strongly. Similar but less pronounced results were observed on multi-year ice. The effect was not noted on fresh-water ice.

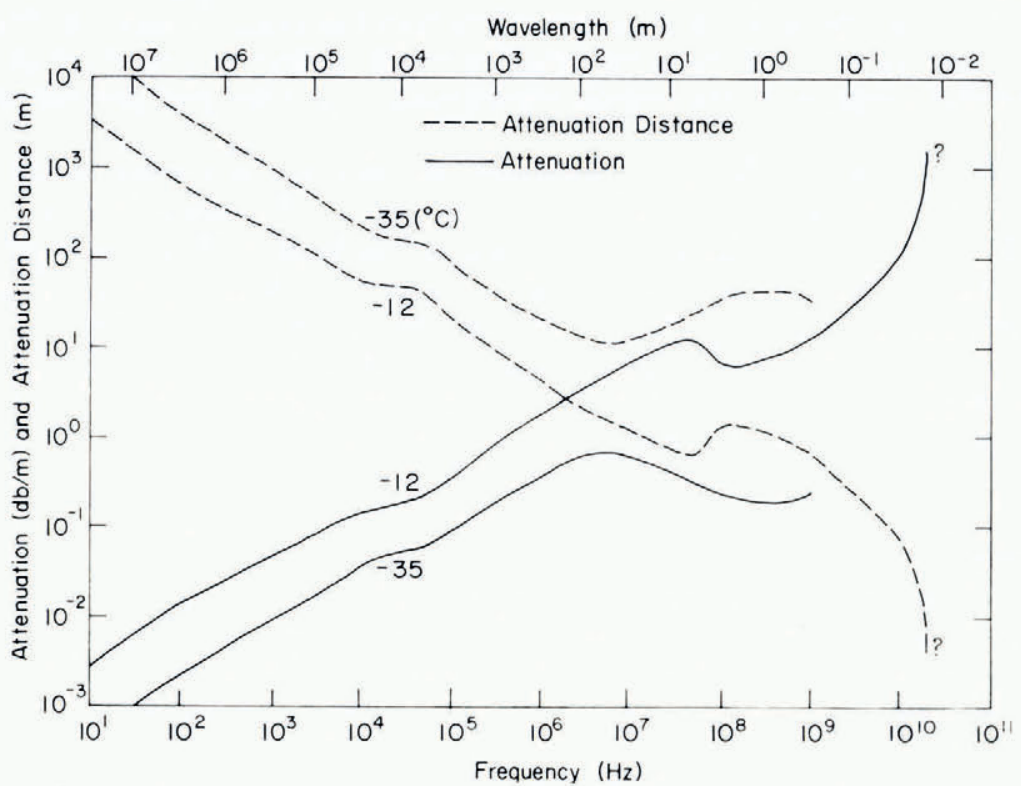

Fig. 18. Attenuation and attenuation distance versus frequency for electromagnetic radiation penetrating first-year sea ice (Addison, 1969; Vant, unpublished).

In some fast-ice areas the orientation of the maximum return remained roughly constant over distances of the order of kilometers. In other areas characterized by obviously rotated ice plates, marked changes in the orientation of the maximum occurred over distances of meters. It has been tentatively suggested that these effects are the result of a highly preferred crystal orientation in the lower portion of the ice sheet and the one check that was made suggests that the maximum return is received when the output field is oriented roughly parallel to the $c$-axis direction (normal to the platy substructure). These experiments and their interpretation are, as yet, hardly conclusive. Nevertheless, if they are correct they will provide a link between the observations mentioned in the first portion of this review detailing the increasing evidence for the existence of large domains of ice crystals with similar $c$-axis orientations in the lower portions of thicker ( $>\mathrm{I} \mathrm{m}$ ) fast ice and the fact, noted several times in our discussion of mechanical properties, that changes in crystal orientation correspond to large differences in observed strength. 


\section{Conclusions}

In the above we have attempted to provide an introductory assessment of what is known about the engineering properties of sea ice by discussing its mechanical, thermal, and electrical properties. We have not quoted all the pertinent references but we have to the best of our knowledge mentioned all the major studies relating to this highly specialized field of study. Works that we have omitted should be readily locatable via the bibliographies in the referenced material. Because of space limitations we have been unable to discuss adequately differences in experimental results as related to differences in measurement techniques. We caution the reader against using any of the experimental values quoted here without thoroughly investigating the techniques used in making the measurements. In discussing the available results, we have tried to stress gaps and inconsistencies in the data base. Specific obvious examples are the conflicting results on whether both $E$ and $\sigma_{\mathrm{f}}$ go to zero at high values of $\nu(>0.3)$ or have values that are essentially independent of $\nu_{\mathrm{b}}$. This is particularly important inasmuch as the lower portion of every piece of sea ice contains ice that has brine volumes in or near to this range. Also important is the effect of variations in strain- or stress-rate, of sample size, of the loading direction in relation to the crystal orientation, and of the precipitation of solid salts within the ice.

There is clearly much to be done. However, we feel that if proper standardization of testing techniques is followed by combined laboratory and (when necessary) field testing, we should be able to resolve many of the remaining problem areas within a reasonable period of time. Writing this review has helped clarify many of these problem areas for us. We hope that it will serve as a similar aid to the reader. We anticipate that considerable advances will be made in our understanding of the engineering properties of sea ice within the next few years. It is certainly essential that such advances be made if the engineering problems associated with increased off-shore activities over the Arctic continental shelves are to be analyzed using good quality data as opposed to "informed guesses".

\section{Acknowledgements}

Dr Weeks' contribution to this paper was supported by MARAD, by the National Oceanic and Atmospheric Agency/Bureau of Land Management Arctic Outer Continental Shelf Environmental Assessment Program (Research Unit No. 88) and by the International Standardization Fund.

\section{REFERENGES}

Ackley, S. F., and others. 1974. Thickness and roughness variations of Arctic multi-year sea ice, by S. F. Ackley, W. D. Hibler III, F. Kugzruk, A. Kovacs and W. F. Weeks. (In Ocean '74 IEEE International Conference on Engineering in the Ocean Environment, Vol. 1, p. 109-1 7.)

Addison, J. R. 1969. Electrical properties of saline ice. Journal of Applied Physics, Vol. 40, No. 8, p. 3105-14.

Addison, J. R. 1970. Electrical relaxation in saline ice. Journal of Applied Physics, Vol. 41, No. 1, p. 54-63.

Addison, J. R. 1975. Electrical properties of saline ice at $\mathrm{i} \mathrm{kHz}$ down to $-150^{\circ} \mathrm{C}$. Fournal of Applied Physics, Vol. 46, No. 2, p. 513-22.

Airaksinen, K. I974. Free beam tests and friction tests at Pond Inlet, N.W.T. Polarforschung, Jahrg. 44, Nr. I, p. $7 \mathrm{I}-75$.

Anderson, D. L. I958[a]. A model for determining sea ice properties. (In Arctic sea ice. Washington, D.C.,

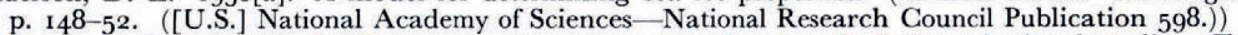

Anderson, D. L. $1958[\mathrm{~b}]$. Preliminary results and review of sea ice elasticity and related studies. Transactions of the Engineering Institute of Canada, Vol. 2, No. 3, p. I16-22.

Anderson, D. L. I960. The physical constants of sea ice. Research, Vol. 13, No. 8, p. 310-18.

Anderson, D. L., and Weeks, W. F. 1958. A theoretical analysis of sea-ice strength. Transactions. American Geophysical Union, Vol. 39, No. 4, p. $632-40$.

Arnol'd-Alyab'yev, V. I. I925. O metodakh issledovaniya l'dov Finskogo zaliva s ledokolov [Methodology of ice study from ice-breakers in the Gulf of Finland]. Zhurnal Geofiziki $i$ Meteorologii, Tom 2, p. 79-88.

Arnol'd-Alyab'yev, V. I. 1938. The external friction of ice. Union Internationale de Géodésie et de Géophysique. Association Internationale d'Hydrologie Scientifique. Sixième assemblée générale à Edimbourg, septembre 1936. Bulletin No. 23 , p. $563-70$. 
Arnol'd-Alyab'yev, V. I. r939. O prochnosti l'da Barentsova i Karskogo morei [Strength of the ice in the Barents and Kara seas]. Problemy Arktiki, i 939, No. 6, p. 2 I-30.

Assur, A. 1958. Composition of sea ice and its tensile strength. (In Arctic sea ice. Washington, D.C., p. Io6-38. ([U.S.] National Academy of Sciences-National Research Council Publication 598.))

Assur, A. ${ }^{1967}$. Flexural and other properties of sea ice sheets. (In Ōura, H., ed. Physics of snow and ice: international conference on low temperature science. . . I966. . . Proceedings, Vol. I, Pt. I. [Sapporo], Institute of Low Temperature Science, Hokkaido University, p. $557-67$.)

Bogorodskiy, V. V., and Tripol'nikov, V. P. I975. Radiozondirovaniye morskogo l'da [Radio sounding of sea ice]. Trudy Arkticheskogo i Antarkticheskogo Nauchno-Issledovatel'skogo Instituta, Tom 326, p. 29-31.

Brown, J. H. I963. Elasticity and strength of sea ice. (In Kingery, W. D., ed. Ice and snow; properties, processes, and applications: proceedings of a conference held at the Massachusetts Institute of Technology, February $12-16,1962$. Cambridge, Mass., M.I.T. Press, p. 79-106.)

Brown, J. H., and Howick, E. E. 1958. Physical measurements of sea ice. U.S. Navy Electronics Laboratory. Research and Development Report 825.

Buch, A., and Goldschmidt, S. 1970. Influence of porosity on elasticity moduli of sintered materials. Materials Science and Engineering, Vol. 5, No. 2, p. 1 I $1-18$.

Bunt, J. S. 1960. Introductory studies: hydrology and plankton, Mawson, June 1956-February I957. $A \mathcal{N} A R E$ Scientific Reports. Ser. B (III). Oceanography, Hydrology. Publication No. 56.

Butkovich, T. R. 1956. Strength studies of sea ice. U.S. Snow, Ice and Permafrost Research Establishment. Research Report 20.

Butkovich, T. R. 1959. On the mechanical properties of sea ice, Thule, Greenland, 1957. U.S. Snow, Ice and Permafrost Research Establishment. Research Report 54 .

Campbell, K. J., and Orange, A. S. 1974. The electrical anisotropy of sea ice in the horizontal plane. Fournal of Geophysical Research, Vol. 79, No. 33, p. 5059-63.

Carter, D. S. [1972.] Brittle fracture of polycrystalline ice under compressive loadings. (In [International Association of Hydraulic Research.] I.A.H.R. symposium: ice and its action on hydraulic structures, Leningrad, USSR, 26-29 September 1972. [Leningrad, International Association of Hydraulic Research], [Vol. I], p. $62-7$ I.)

Coble, R. L., and Kingery, W. D. 1956. Effect of porosity on physical properties of sintered alumina. Fournal of the American Ceramic Society, Vol. 39, No. I 1, p. 377-85.

Cox, G. F. N., and Weeks, W. F. 1974. Salinity variations in sea ice. Fournal of Glaciology, Vol. 13, No. 67, p. $109-20$.

Croasdale, K. R. I974. Crushing strength of Arctic ice. (In Reed, J. C., and Sater, J. E., ed. The coast and shelf of the Beaufort Sea. Proceedings of a symposium on Beaufort Sea coast and shelf research. Arlington, Virginia, Arctic Institute of North America, p. 377-99.)

DeLoor, G. P. Unpublished. Dielectric properties of heterogeneous mixtures. [Ph.D. thesis, University of Leiden, Netherlands, r 956.]

Dixit, B., and Pounder, E. R. 1975. The specific heat of saline ice. Journal of Glaciology, Vol. 14, No. 72, p. 459-65.

Dykins, J. E. 1970. Ice engineering - tensile properties of sea ice grown in a confined system. U.S. Naval Civil Engineering Laboratory. Technical Report R689.

Dykins, J. E. 197I. Ice engineering material properties of saline ice for a limited range of conditions. U.S. Naval Givil Engineering Laboratory. Technical Report R720.

Enkvist, E. 1972. On the ice resistance encountered by ships operating in the continuous mode of icebreaking. Swedish Academy of Engineering Sciences in Finland. Report No. 24.

Finke, S. 1972. Untersuchungen zum Verformungsverhalten des Meereises im Eclipse Sound (Baffin Island) und Messungen des Reibungskoeffizienten Stahl-Eis. Polarforschung, Jahrg. 42, Nr. 2, p. 75-81 .

Finkel'shteyn, M. I., and others. 1975. O distantsionnom izmerenii tolshchiny morskogo l'da metodami radiolokatsii [Remote measurement of the thickness of sea ice by radar methods]. [By] M. I. Finkel'shteyn, V. A. Kutev, V. G. Glushnev, Ye. I. Lazarev. Trudy Arkticheskogo i Antarkticheskogo Nauchno-Issledovatel'skogo Instituta, Tom 326 , p. 5 I-54.

Frankenstein, G. E. 1968. Strength of ice sheets. Canada. National Research Council. Associate Committee on Geotechnical Research. Technical Memorandum No. 92, p. 79-87.

Frankenstein, G. E., and Garner, R. 1967. Equations for determining the brine volume of sea ice from -o.5 to -22.9 ${ }^{\circ}$. Journal of Glaciology, Vol. 6, No. 48, p. $943-44$.

Fujino, K. I96o. Hiteikōhō ni yoru kaihyō hyōkō sokutei no kokoromi. I [An attempt to estimate the thickness of sea ice by the electric resistivity method. I]. Teion-kagaku: Low Temperature Science, Ser. A, [No.] 19, p. $203^{-1} 3$.

Fujino, K. ${ }^{1967}[\mathrm{a}]$. Electrical properties of sea ice. (In Ōura, H., ed. Physics of snow and ice: international conference on low temperature science. . . 1966. ... Proceedings, Vol. I, Pt. I. [Sapporo], Institute of Low Temperature Science, Hokkaido University, p. 633-48.)

Fujino, K. I967[b]. Kaihyō no yūdenteki seishitsu ni kansuru kenkyū [Dielectric properties of sea ice]. Teionkagaku: Low Temperature Science, Ser. A, [No.] 25, p. 127-69.

Gow, A. J. 1977. Flexural strength of ice on temperate lakes. Fournal of Glaciology, Vol. 19, No. 81, p. 247-56.

Grothues-Spork, H. 1974. Aufmessung der Strömungen unter dem Eis des Eclipse Sound (Baffin Island) und Bestimmung von Reibungskoeffizienten zwischen Stahl und Eis. Polarforschung, Jahrg. 44, Nr. 1, p. $76-82$.

Hashin, Z. 1970. Theory of composite materials. (In Wendt, S. W., and others, ed. Mechanics of composite materials, edited by S.W. Wendt, H. Liebowitz and N. Perrone. Proceedings of the fifth Symposium on Naval Structural Mechanics [Philadelphia, May 1967]. New York, Pergamon Press, p. 201-42. (Office of Naval Research Structural Mechanics Series.)) 
Hawkes, I., and Mellor, M. 1972. Deformation and fracture of ice under uniaxial stress. Fournal of Glaciology, Vol. i i, No. 61, p. 103-31.

Haynes, F. D., and Mellor, M. 1977. Measuring the uniaxial compressive strength of ice. Fournal of Glaciology, Vol. 19, No. 81, p. 213-23.

Hibler, W. D., III, and others. 1972. Top and bottom roughness of a multiyear ice floe, by W. D. Hibler, S. F. Ackley, W. F. Weeks and A. Kovacs. AID JEX Bulletin, No. 13, p. 77-91.

Hirayama, K., and others. 1974. An investigation of ice forces on vertical structures, by K. Hirayama, 7. Schwar $z$ and H. C. $W u$. Iowa City, Iowa Institute of Hydraulic Research, University of Iowa. (IIHR Report No. I $5^{8 .)}$

Hoekstra, P., and Cappillino, P. I97 I. Dielectric properties of sea and sodium chloride ice at UHF and microwave frequencies. Journal of Geophysical Research, Vol. 76, No. 20, p. 4922-31.

Hutter, K. I973. On the fundamental equations of floating ice. Mitteilungen der Versuchsanstalt für Wasserbau, Hydrologie und Glaziologie an der Eidg. Technischen Hochschule (Zürich), Nr. 8.

Hutter, K. I975. Floating sea ice plates and the significance of the dependence of the Poisson ratio on brine content. Proceedings of the Royal Society of London, Ser. A, Vol. 343 , No. 1632, p. 85-108.

IAHR. 1975. Report of the task-committee on standardizing testing methods for ice. (In Frankenstein, G. E., ed. Proceedings. Third International Symposium on Ice Problems, 18-21 August 1975, Hanover, New Hampshire. [Hanover, N.H.], International Association of Hydraulic Research. Committee on Ice Problems, p. 607-18.)

Jansson, J.-E. 1956. Ice-breakers and their design. European Shipbuilding, Vol. 5, No. 5, p. 112-28; No. 6, p. $143-5 \mathrm{I}$.

Johnson, P. R. [1972.] The modulus of elasticity of sea ice shown by direct tension and compression tests of small specimens. (In [International Association of Hydraulic Research.] I.A.H.R. symposium: ice and its action on hydraulic structures, Leningrad, USSR, 26-29 September 1972. [Leningrad, International Association of Hydraulic Research], [Vol. i], p. 8-16.)

Katona, M. G., and Vaudrey, K. D. 1973. Ice engineering - summary of elastic properties research and introduction to viscoelastic and nonlinear analysis of saline ice. U.S. Naval Civil Engineering Laboratory. Technical Report R797.

Khokhlov, G. P. I97o. Rezul'taty eksperimental'nykh issledovanii elektricheskikh kharakteristik arkticheskogo morskogo l'da v diapazone chastot 100 gts-1 Mgts [Results of experimental measurements of the electrical parameters of Arctic sea ice at frequencies between $100 \mathrm{~Hz}$ and $\mathrm{I} \mathrm{MHz}]$. Trudy Arkticheskogo $i$ Antarkticheskogo Nauchno-Issledovatel'skogo Instituta, Tom 295, i970, p. 83-88.

Kohnen, H. r972. Seismic and ultrasonic measurements on the sea ice of Eclipse Sound near Pond Inlet, N.W.T. in northern Baffin Island. Polarforschung, Jahrg. 44, Nr. 2, p. $66-74$.

Kohnen, H. [1976.] On the DC-resistivity of sea ice. Zeitschrift für Gletscherkunde und Glazialgeologie, Bd. I I, Ht. 2, 1975, p. 143-54.

Korzhavin, K. N. I962. Vozdeystviye l'da na inzhenernye sooruzheniya [Action of ice on engineering structures]. Novosibirsk, Izdatel'stvo Sibirskogo Otdel, Akademiya Nauk SSSR. [English translation: U.S. Cold Regions Research and Engineering Laboratory. Translation TL 26o, 1971.]

Kovacs, A. In press. Sea ice thickness profiling and under-ice oil entrapment. [Paper presented at ninth Annual Offshore Technology Conference, Houston, Texas, 1977.]

Krylov, A. N. Igor. Nablyudeniya nad krepost'yu l'da [Observations of ice strength]. (In Makarov, S. O., ed. "Yermak" vo l'dakh. St. Petersburg, Tip. Ye. Yedokimov, p. 418-35.)

Langleben, M. P., and Pounder, E. R. 1963. Elastic parameters of sea ice. (In Kingery, W. D., ed. Ice and snow; properties, processes, and applications: proceedings of a conference held at the Massachusetts Institute of Technology, February $12-16$, 1962 . Cambridge, Mass., M.I.T. Press, p. 69-78.)

Lavrov, V. V. ig69. Deformatsiya $i$ prochnost l'da. Leningrad, Gidrometeorologicheskoye Izdatel'stvo. [English translation: Deformation and strength of ice. Translated by T. Pelz. Edited by G. N. Yakovlev. Jerusalem, Israel Program for Scientific Translations Ltd. Available from National Technical Information Service, U.S. Dept. of Commerce, Springfield, Virginia 22151.]

Lewis, E. L. 1967. Heat flow through winter ice. (In Ōura, H., ed. Physics of snow and ice: international conference on low temperature science. ... I966. ... Proceedings, Vol. I, Pt. I. [Sapporo], Institute of Low Temperature Science, Hokkaido University, p. 6 I $1-3 \mathrm{I}$.)

Lewis, J. W., and Edwards, R. Y. I97I. Methods for predicting icebreaking and ice resistance characteristics of icebreakers. Transactions of the Society of Naval Architects and Marine Engineers, Vol. 78, p. 21 3-49.

Lin'kov, Ye. M. 1958. Izucheniye uprugikh svoystv ledyanogo pokrova v Arktike [Study of the elastic properties of an ice cover in the Arctic]. Vestnik Leningradskogo Universiteta, Tom 13, No. 4, Seriya Fiziki i Khimii, Vyp. 1, p. 17-22.

Lofgren, G., and Weeks, W. F. I969. Effect of growth parameters on substructure spacing in $\mathrm{NaCl}$ ice crystals. Journal of Glaciology, Vol. 8, No. 52, p. $153-64$.

Määttänen, M. 1976. On the flexural strength of brackish water ice by in-situ tests. (In Proceedings of the third International Conference on Port and Ocean Engineering under Arctic Conditions held in Fairbanks, Alaska, University of Alaska, II-15 August 1975. Vol. I. Fairbanks, Alaska, Institute of Marine Science, University of Alaska, p. 349-59.)

McNeill, D., and Hoekstra, P. 1973. In-situ measurements on the conductivity and surface impedance of sea ice at VLF. Radio Science, Vol. 8, No. 1, p. 23-30.

Makarov, S. O. r gor. Zametki po ledovedeniyu [Notes on ice science]. (In Makarov, S. O., ed. "Yermak" vo l'dakh. St. Petersburg, Tip. Ye. Yedokimov, p. 388-4 i 7.)

Malmgren, F. 1927. On the properties of sea ice. The Norwegian North Polar Expedition with the "Maud", 19181925. Scientific results, Vol. 1, No. 5 .

Maykut, G. r976. Energy exchange over young sea ice in the central Arctic. AID FEX Bulletin, No. 31, p. 45-74. 
Maykut, G., and Untersteiner, N. 1969. Numerical prediction of the thermodynamic response of Arctic sea ice to environmental changes. Santa Monica, California, Rand Corporation. (RM-6og3-PR.)

Milano, V. R. 1962. Notes on icebreaker design. Journal of the American Society of Naval Engineers, Vol. 74, No. 1, p. $43^{-} 5^{\mathrm{I}}$.

Nazintsev, Yu. L. I959. Eksperimental'noye opredeleniye teployemkosti i temperaturoprovodnosti morskogo l'da [Experimental determination of the specific heat and thermometric conductivity of sea ice]. Problemy Arktiki i Antarktiki, Vyp. 1, p. 65-7i.

Ono, N. I966. Kaihyō no netsuteki seishitsu no kenkyū. III. Kaihyō no hinetsu ni tsuite [Thermal properties of sea ice. III. On the specific heat of sea ice]. Teion-kagaku: Low Temperature Science, Ser. A, [No.] 24, p. $249-58$.

Ono, N. r 967 . Specific heat and heat of fusion of sea ice. (In Oura, H., ed. Physics of snow and ice: international conference on low temperature science. ... 1966. ... Proceedings, Vol. I, Pt. I. [Sapporo], Institute of Low Temperature Science, Hokkaido University, p. 599-6ro.)

Ono, N. 1968. Kaihyō no netsuteki seishitsu no kenkyū. IV. Kaihyō no netsuteki na shoteisū. [Thermal properties of sea ice. IV. Thermal constants of sea ice]. Teion-kagaku: Low Temperature Science, Ser. A, [No.] 26, p. 329-49.

Paige, R. A., and Lee, C. W. I967. Preliminary studies on sea ice in McMurdo Sound, Antarctica, during "Deep Freeze 65". Journal of Glaciology, Vol. 6, No. 46, p. $5^{1} 5^{-28}$.

Peschanskiy, I. S. I 967 . Ledovedeniye $i$ ledotekhnika. Izdaniye 2-ye, dopolnennoye $i$ pererabotannoye [Glaciology and ice technology. 2nd edition, augmented and revised]. Leningrad, Gidrometeorologicheskoye Izdatel'stvo.

Peyton, H. R. 1966. Sea ice strength. College, Alaska, Geophysical Institute, University of Alaska. (UAG R-182.)

Ryvlin, A. Ya., and Petrov, Ye. Yu. r965. K voprosu ob eksperimental'nom opredelenii koeffitsientov treniya l'da naturnykh usloviyakh [On experimental determination of ice friction coefficients under natural conditions]. Problemy Arktiki i Antarktiki, Vyp. 2 I, p. 66-7г.

Sackinger, W. M., and Byrd, R. C. 1972. Reflection of millimeter waves from snow and sea ice. University of Alaska. Institute of Arctic Environmental Engineering. Report 7203.

Schwarz, J. [1971.] The pressure of floating ice-fields on piles. (In [International Association of Hydraulic Research.] I.A.H.R. symposium: ice and its action on hydraulic structures, Reykjavik, Iceland, [8]-Io September I97o. [Delft, International Association of Hydraulic Research], paper 6.3.)

Schwarz, J. 1975. On the flexural strength and elasticity of saline ice. (In Frankenstein, G. E., ed. Proceedings. Third International Symposium on Ice Problems, 18-2I August 1975, Hanover, New Hampshire. [Hanover, N.H.], International Association of Hydraulic Research. Committee on Ice Problems, p. 373-85.)

Schwerdtfeger, P. I963. The thermal properties of sea ice. Journal of Glaciology, Vol. 4, No. 36, p. $789-807$.

Slesarenko, Yu. Ye., and Frolov, A. D. [1974.] Comparison of elasticity and strength characteristics of salt-water ice. (In [International Association of Hydraulic Research.] I.A.H.R. symposium: ice and its action on hydraulic structures, Leningrad, USSR, 26-29 September 1972. [Leningrad, International Association of Hydraulic Research], [Vol. 2], p. $85-87$.)

Smith, D. D. 1964. Ice lithologies and structure of ice island Arlis II. Journal of Glaciology, Vol. 5, No. 37, p. $17-38$.

Tabata, T. 196o. Kaihyō no ryokugakuteki seishitsu no kenkyū. V. Mage hakai kyōdo no sckutei [Studies on mechanical properties of sea ice. V. Measurement of flexural strength]. Teion-kagaku: Low Temperature Science, Ser. A, [No.] 19, p. I87-201.

Tabata, T., and others. 1967. Studies of the mechanical properties of sea ice. XI. The flexural strength of sea ice in situ, by T. Tabata, K. Fujino and M. Aota. (In Oura, H., ed. Physics of snow and ice: international conference on low temperature science. ... I966. . . Proceedings, Vol. I, Pt. I. [Sapporo], Institute of Low Temperature Science, Hokkaido University, p. 539-50.)

Tabata, T., and others. 1975. Bosunia-wan kaikyō chōsa. II. Magekyōdo no sokutei [Ice study in the Gulf of Bothnia. II. Measurements of flexural strength]. [By] T. Tabata, Y. Suzuki, M. Aota. Teion-kagaku: Low Temperature Science, Ser. A, [No.] 33, p. 199-206.

Thomas, C. W. ${ }^{1963}$. On the transfer of visible radiation through sea ice and snow. Fournal of Glaciology, Vol. 4 , No. 34 , p. $48 \mathrm{I}-84$.

Tsurikov, V. L. 1940. Problema prochnosti morskogo l'da [The problem of ice strength]. Severnyy Morskoy Put', No. I6, p. $45^{-74}$.

Tsurikov, V. L. I947[a]. K voprosu o vliyanii polostnosti l'da na yego prochnost [The problem of the influence of the ice porosity on its strength]. Trudy Gosudarstvennogo Okeanograficheskogo Instituta, Tom 2, No. 14, p.66-88.

Tsurikov, V. L. I947[b]. O vliyanii solenosti morskogo l'da na yego prochnost [The influence of the salinity of sea ice on its strength]. Trudy Gosudarstvennogo Okeanograficheskogo Instituta, Tom 2, No. 14, p. 89-1o8.

Tsurikov, V. L. 1976. Zhidkaya faza v morskikh l'dakh [The fluid phase in sea ice]. Moscow, Izdatel'stvo "Nauka".

Untersteiner, N. I96r. On the mass and heat budget of Arctic sea ice. Archiv für Meteorologie, Geophysik und Bioklimatologie, Ser. A, Bd. 12, Ht. 2, p. 151-82.

Untersteiner, N. 1964. A nomograph for determining heat storage in sea ice. Journal of Glaciology, Vol. 5, No. 39, p. $35^{2}$.

Vant, M. R. Unpublished. A combined empirical and theoretical study of the dielectric properties of sea ice over the frequency range $100 \mathrm{MHz}$ to $40 \mathrm{GHz}$. [Ph.D. thesis, Dept. of Electronics, Faculty of Engineering, Carleton University, Ottawa, 1976.]

Vant, M. R., and others. 1974. Dielectric properties of fresh and sea ice at ro and $35 \mathrm{GHz}$, [by] M. R. Vant, R. B. Gray, R. O. Ramseier, V. Makios. Journal of Applied Physics, Vol. 45, No. I 1, p. $4712-17$.

Vaynberg, B. P., and others. 1940. Led, svoystva, vozniknoveniye $i$ ischeznoveniye l'da [Ice, its properties, appearance and disappearance]. [By] B. P. Vaynberg, V. Ya. Al'tberg, V. E. Arnol'd-Alyab'yev, M. P. Golovkov. Moscow, Gosudarstvennoye Izdatel'stvo Tekhniko-Teoretischeskoy Literatury. 
Weeks, W. F. 1968. Understanding the variations of the physical properties of sea ice. (In Currie, R. I., ed. SCAR/SCOR/IAPO/IUBS symposium on Antarctic oceanography [Santiago, Chile, 1966]. Cambridge, Scott Polar Research Institute, p. I 73-90.)

Weeks, W. F., and Anderson, D. L. 1958. An experimental study of strength of young sea ice. Transactions. American Geophysical Union, Vol. 39, No. 4, p. $64 \mathrm{I}-47$.

Weeks, W. F., and Assur, A. 1967. The mechanical properties of sea ice. U.S. Cold Regions Research and Engineering Laboratory. Cold regions science and engineering. Hanover, N.H., Pt. II, Sect. C 3 .

Weeks, W. F., and Assur, A. 1969. Fracture of lake and sea ice. U.S. Cold Regions Research and Engineering Laboratory. Research Report 269.

Weeks, W. F., and Lee, O. S. 1958. Observations on the physical properties of sea ice at Hopedale, Labrador. Arctic, Vol. I I, No. 3, p. 1 $34-55$.

Weeks, W. F., and Lee, O.S. 1962. The salinity distribution in young sea ice. Arctic, Vol. 15, No. 2, p. $92-108$.

Weller, G. E. 1968. The heat budget and heat transfer processes in Antarctic plateau ice and sea ice. $A N A R E$ Scientific Reports, Ser. A (IV). Glaciology. Publication No. 102.

Wentworth, F. L., and Cohn, M. I964. Electrical properties of sea ice at o. I to $30 \mathrm{Mc} / \mathrm{s}$. Journal of Research. (National Bureau of Standards.) Section D. Radio Science, Vol. 68D, No. 6, p. 681-91.

$\mathrm{Wu}, \mathrm{H}$. C., and others. 1976. Fracture in the compression of columnar grained ice, by H. C. Wu, K. J. Chang and J. Schwarz. Engineering Fracture Mechanics, Vol. 8, No. 2, p. 365-72.

Zubov, N. N. 1945. L'dy Arktiki [Arctic ice]. Moscow, Izdatel'stvo Glavsevmorputi.

Zukriegel, J. I935. Cryologia maris. Prague, Geografical Institute of the Charles IV University. (Travaux Géographiques Tchèques, 15.$)$

\section{DISGUSSION}

S. F. Ackley: In comparing your results to Peyton's you mentioned the variation of strength with growth direction. However, the variation of crystal orientation with thickness is also important in this comparison. Were the fabric variations comparable to Peyton's; i.e. was the $c$-axis basically horizontal where you indicate the converse to Peyton's results?

J. Schwarz: As mentioned in our paper, the ice was frozen very rapidly from water of $10 \%$ salinity, which caused the salinity within the ice to be $2.7 \%$. The $c$-axis of the Baltic sea ice was horizontal and the structure of the ice crystals very similar to that of young sea ice.

P. TRYDE: Stratified water is known to develop in the Baltic Sea, with low salinity water at the surface. From where were the Baltic Sea samples taken?

Schwarz: The ice was taken from Lübecker Bucht. The relatively high salinity within the ice indicates little or no stratification.

K. R. Groasdale: You have mentioned small-scale strength tests on sea ice, and the use of standardized test techniques. What special precautions are needed in handling samples to ensure that the brine distributions are not disturbed?

Schwarz: Brine drainage during sea-ice testing is indeed a serious problem. Unless tests are carried out below $-20^{\circ} \mathrm{C}$ drainage cannot be avoided. Professor Tabata has agreed to study the effect of brine drainage on the strength of sea ice as a function of time and temperature. The results will be used by the Standardization Task Group to establish guide-lines for testing sea ice.

Groasdale: Multi-year ice will probably govern ice forces on off-shore structures in the Beaufort Sea. Does this form of sea ice present any special problems in terms of specifying strength properties?

W. F. WEEKs: I feel that multi-year ice is easier to study than first-year ice. The reason for this is its low salinity which minimizes the problems associated with brine drainage.

R. Frederking: How important do you think it is to study sea ice from November to January in order to understand the behavior and properties observed in May? 
WeEks: It is very desirable to be able to follow the sequential changes in the characteristics of a given sheet of sea ice in that this gives you insight into how things get to be the way they are. However, if it is not possible to do this, it is still possible to obtain very useful information by taking the ice that exists at the time you are there and heating or cooling it to the state that interests you.

S. F. Ackley: Regarding the tension tests by Dykins, you referred to the vertical and horizontal directions. Are these the growth or the $c$-axis directions? Do you then see a switch-over in strength in tension as compared to compression relative to the $c$-axis direction?

Schwarz: In the tension tests carried out by Dykins the vertical and growth directions are identical, as are the horizontal and $c$-axis directions. In the case of anisotropic ice the strength in compression and in tension seems to be coupled in such a way that if the uniaxial compressive strength of a sample, loaded in the vertical direction, is smaller than in the horizontal, the equivalent tensile strength (also vertical) should be higher. 